Amasya İlahiyat Dergisi - Amasya Theology Journal

ISSN 2667-7326 | e-ISSN 2667-6710

Aralık / December 2020, 15: 105-142

\title{
Klasik ve Modern Kaynaklarda İlk Cinayet Kıssası (Maide 5/27-31): Tefsir Metodolojisi Açısından Mukayeseli Bir İnceleme
}

\section{Yunus Emre GÖRDÜK}

Doç. Dr., Balıkesir Üniversitesi, İlahiyat Fakültesi, Tefsir Anabilim Dalı

Associate Professor, Balıkesir University, Faculty of Theology,

Department of Tafsir

Balıkesir, Turkey

yunusemre.gorduk@gmail.com

orcid.org/0000-0001-7603-7705

\section{Makale Bilgisi / Article Information}

Makale Türü / Article Types: Araştırma Makalesi / Research Article

Geliş Tarihi / Received: 17 Eylül / September 2020

Kabul Tarihi / Accepted: 04 Kasım / November 2020

Yayın Tarihi / Published: 30 Aralık / December 2020

Yayın Sezonu / Pub. Date Season: Aralık / December

Sayı / Issue: 15 Sayfa / Pages: 105-142

Atıf / Cite as: Gördük, Yunus Emre. "Klasik ve Modern Kaynaklarda İlk Cinayet Kıssası (Maide 5/27-31): Tefsir Metodolojisi Açısından Mukayeseli Bir İnceleme [The Story of the First Murder (Surah al-Maidah/27-31) in Classic and Modern Sources: A Comparative Examination in Terms of Tafsir Methodology]". Amasya İlahiyat Dergisi-Amasya Theology Journal 15 (December 2020): 105-142.

https://doi.org/10.18498/amailad.796592.

İntihal / Plagiarism: Bu makale, en az iki hakem tarafından incelendi ve intihal içermediği teyit edildi. / This article has been reviewed by at least two referees and scanned via a plagiarism software.

Copyright () Published by Amasya Üniversitesi, İlahiyat Fakültesi / Amasya University, Faculty of Theology, Amasya, 05100 Turkey. All rights reserved. https://dergipark.org.tr/amailad. 
106 | Y. Emre GÖRDÜK / Klasik ve Modern Kaynaklarda Illk Cinayet Kıssası (Maide 5/27-31):

Tefsir Metodolojisi Açısından Mukayeseli Bir İnceleme

\section{The Story of the First Murder (Surah al-Maidah/27-31) in Classic and Modern}

Sources: A Comparative Examination in Terms of Tafsir Methodology

\section{Abstract}

In this article, the "qissa of the first murder" (al-Maidah/27-31) is discussed methodologically in the point of classical tafsir sources and modern studies. The qissa consists of two elements which are the phrases "two sons of Adam" and the "crow's guidance to the murderer". In general, the commentators consider that the "Adam" indicates the Prophet Adam. The crow was sent to show how the body would be buried because the murder committed is the first murder on earth that does not know what to do with a dead body. In this general opinion, as well as the proofs of verses words and in-text contex elements, authentic hadiths, which are the main references of the tafsir, and narrations of companion and followers were taken into consideration. Along with other hadiths; especially it is seen that it is not possible to discredite the following hadīth narration of Masruq Ibn al-Ajda reported from Abdullah Ibn Mas'ud that is included in almost all authentic hadith sources as "no person is killed wrongfully, but a share of responsibility for his blood will be upon the first son of Adam, because he was the first one to kill". By adding the views of the companions, followers and the alliance of the ummah, it has become clear who the killer and victim are. In addition, the crow sent to show how to bury the dead body that confirms this view. Until the 20th century, it is seen that all of the commentators are in alliance on this view. The view referred to personalities such as Hasan al-Bașrī and al-Dahhāāk is that the two people mentioned in the qissa are from children of Israel. However it is evident from other narrations of this view is not related to the idea that Adam and his wife were not the first human couple. Therefore, there is not an unique understanding of Adam that is accepted by everyone. In the explanations made by the commentators taken into consideration the different verses related to the subject. On the other hand, the literal meaning of the verses was taken as a basis and there was no need for ta'wīl because of any ambigious expression. These are also constitute the basic elements of the method followed in classical tafsirs. As for the evolutionist point of view; there is no such phenomenon as the first children of the first two people. Because in evolution, it is impossible to mention such a thing as the first two people. One of the dominant elements that shapes the modern exegesis understanding is this style of approach. According to the claim that the qissa's are symbolic, the verse statements are not important already. In this aspect, it is emphasized that both there is no reality of the story 
Y. Emre GÖRDÜK / The Story of the First Murder (Surah al-Maidah/27-31) in Classic and Modern Sources: A Comparative Examination in Terms of Tafsir Methodology I 107 and is mentioned in reference to the Torah. But the similar story mentioned in the Torah, which is originally as divine, does not contradict its inclusion in the Qur'an as a truth. As a matter of fact, the Qur'an has been modifier and corrective as well as supplemantary and confirmative on the texts of Torah and Bible. In addition, the story of Abel and Cain in Torah is not mentioned the crow. According to the symbolist understanding, the Qur'an conveys a story that is claimed to be an imaginary product, and adds unfounded element to it during the transfer. This is a delusion that is not based on any evidence. It is certain that Allah, who knowledge encompasses everything and describes what is told in the Quran as truth, does not need to tell an imaginary story to show the guidance. Moreover, if the qissa of the first murder is symbolic, it means that the entire ummah, including the Prophet (pbuh) and the companions, has not understood this since 14th century which means that even mentioning this is absurd. The same inconsistent situation applies to evolutionist interpretations.

As a result, after one of the two brothers killed the other; the killer did not know what to do the dead body, and finally learned from a crow that he should be buried. The literal expression of the verse refers to these two people as "two sons of Adam", and ta'wîl on this issue is far from convincing unless there is a valid evidence. It is seen that both approaches, which are the product of modern times in terms of methodology of Qur'anic Exegesis, are not based on solid scientific basis and lead the way to different contradictions rather than solving problems.

Keywords: Tafsir, Maidah, Qissa, Murder, Methodology.

\section{Klasik ve Modern Kaynaklarda Illk Cinayet Kıssası (Maide 5/27-31): Tefsir Metodolojisi Açısından Mukayeseli Bir İnceleme}

\section{$\ddot{O} z$}

Bu makalede, Mâide suresinde yer alan "illk cinayet kıssası" (27-31. âyetler) klasik tefsir kaynakları ve modern çalışmalar ekseninde metodolojik açıdan ele alınmıştır. Kıssanın en önemli iki unsuru "Âdem'in iki oğlu" lafzıyla kimlerin kastedildiği ve karganın yapmış olduğu rehberliğin ne ifade ettiğidir. Müfessirler genel anlamda, bahsi geçen “Âdem"in Hz. Âdem olduğu kanaatindedir. Gönderilen karga ise cesedin nasıl defnedileceğini göstermiştir. Çünkü işlenen cinayet yeryüzündeki ilk cinayettir ve ölü bir bedenin ne yapılması gerektiği bilinmemektedir. Bu genel kanaatte lafzî delillerin ve metin 
108 | Y. Emre GÖRDÜK / Klasik ve Modern Kaynaklarda Illk Cinayet Kıssası (Maide 5/27-31):

Tefsir Metodolojisi Açısından Mukayeseli Bir İnceleme

içi bağlam unsurlarının yanı sıra tefsirde aslî unsur olan sahîh hadîsler, ardından sahâbe ve tâbiûndan intikal eden rivâyetler esas alınmıştır. Diğer hadîslerle birlikte; özellikle Mesrûk b. el-Ecda"ın, üstâdı Abdullah b. Mes'ûd'dan naklettiği ve neredeyse bütün sahîh kaynaklarda yer alan "Zulmen öldürülen hiç kimse yoktur ki, onun kanından Âdem'in ilk oğluna da bir hisse çıkmasın. Çünkü öldürme (cinayet) yolunu ilk açan odur." hadîsinin cerhi mümkün görünmemektedir. Buna sahâbe ve tâbiûn görüşleri ile ümmetin ittifakı da eklenince kâtil ve maktûlün kimler olduğu konusu netlik kazanmıştır. Ayrıca cesedin nasıl örtüleceğini göstermesi için gönderilen karga da bu kanaati teyit etmektedir. Yirminci asra gelininceye kadar bir iki istisna haricinde müfessirlerin tamamının bu konuda ittifak halinde olduğu görülmektedir. Hasan el-Basrî ve Dahhâk gibi zâtlara atfedilen görüş, kıssada bahsedilen iki kişinin İsrâiloğulları'ndan iki kişi olduğu şeklindedir. Ancak bu görüşün Hz. Âdem ve eşinin ilk insan çifti olmadığ şeklindeki bir düşünceyle ilgisinin olmadığı yine bu zâtlardan gelen başka rivâyetlerle sâbittir. Dolayısıyla herkesçe müsellem bir Âdem anlayışı söz konusudur. Müfessirlerin yapmış oldukları izâhlarda konuyla ilgili farklı âyetler de göz önüne alınmıştır. Öte yandan âyetlerin zâhiri esas tutulmuş ve herhangi bir tereddüt yahut işkâl durumu söz konusu olmadığı için te'vile gerek duyulmamıştır. Bütün bunlar aynı zamanda klasik tefsirlerde izlenen metodun temel unsurlarını oluşturmaktadır.

Buna karşın evrimci bakış açısına göre ilk iki insanın ilk çocukları diye bir olgu söz konusu değildir. Zira evrimde ilk iki insan diye bir şeyden bahsedilmesi mümkün değildir. Modern tefsir anlayışını şekillendiren başat unsurlardan biri bu yaklaşım tarzıdır. Kıssaların sembolik olduğu iddiasına göre ise âyet lafızları zaten önem arz etmemektedir. Bu minvâlde kıssanın bir gerçekliğinin olmadığ1 ve Tevrat'a atfen zikredildiği öne sürülmektedir. Oysaki benzeri bir anlatının asıl itibariyle semâvî olan Tevrat'ta geçmesi, bir hakikat olarak Kur'ân'da da yer almasına aykırı değildir. Nitekim Kur'ân-1 Kerîm, Tevrat ve İncil metinleri/hükümleri üzerinde mübeddil ve musahhih olduğu gibi bazen de mütemmim ve musaddık olmuştur. Ayrıca Tekvin'deki Hâbil-Kâyin kıssasında kargadan bahsedilmemektedir. Sembolikçi anlayışa göre Kur'ân hayal ürünü olduğu iddia edilen bir kıssayı aktarmakta ve bu aktarım esnasında ona asılsız yeni bir unsur daha eklemektedir. Bu ise vehimden ibaret olup herhangi bir delile dayanmamaktadır. İlmi her şeyi ihâta eden ve Kur'ân'da anlatılanları mükerreren "Hakk" diye niteleyen Yüce Allah'ın irşad için hayali bir hikâyeyi anlatmaya muhtaç olmadığı muhakkaktır. Dahası, kıssa eğer sembolikse, 
Y. Emre GÖRDÜK / The Story of the First Murder (Surah al-Maidah/27-31) in Classic and Modern Sources: A Comparative Examination in Terms of Tafsir Methodology I 109

Peygamber (s.a.s.) ve sahabe de dahil bütün ümmet on dört asırdır bunu anlamamış demektir ki bundan söz edilmesi bile abestir. Aynı tutarsız durum evrimci yorumlar için de geçerlidir.

Sonuç itibariyle iki kardeşten biri diğerini katletmiş; daha sonra maktulün ortada kalan cesedini ne yapacağını bilememiş ve nihâyet onun defnedilmesi gerektiğini bir kargadan öğrenmiştir. Âyetin sarih ifadesi bu iki kişi için "Âdem'in iki oğlu" demektedir ve geçerli bir karine/delil olmadığı müddetçe bu konuda yapılacak te'vîl ikna edicilikten uzaktır. Tefsir metodolojisi açısından modern zamanların ürünü olan her iki yaklaşımın da sağlam birer ilmî temele dayanmadığı ve problem çözmekten ziyade farklı çelişkilere kapı araladığı görülmektedir.

Anahtar Kelimeler: Tefsir, Mâide, Kıssa, Cinayet, Metodoloji.

\section{Giriş}

Bu makalede Mâide sûresinin 27-31. âyetlerinde ${ }^{1}$ yer alan ve "İlk cinayet kıssası" diye anılan bölüm incelenecektir. Kıssanın meâli şöyledir: "Onlara Âdem'in iki oğlunun hak (doğru, gerçek) olan haberini oku: Hani o ikisi birer kurban takdim etmişlerdi de birisinden kabul edilmiş, diğerinden kabul edilmemişti. (Kurbanı kabul edilmeyen kardeş), 'Ant olsun ki seni öldüreceğim' dedi. Diğgeri ise 'Allah (kurbanı) ancak takvâ sahiplerinden kabul eder' diye cevap verdi ve ekledi: 'Ant olsun ki sen öldürmek için bana elini uzatsan (bile) ben sana, öldürmek için el uzatacak değilim. Ben, âlemlerin Rabbi olan Allah'tan korkarm. (Ĕğer beni öldürecek olursan;) kuşkusuz isterim ki hem benim günahımı hem de kendi günahın yüklenip ateşe atılacaklardan olasin. Zalimlerin cezası işte budur.' Nihayet nefsi onu, kardeşini öldürmeye itti ve onu öldürdü. Bu yüzden de kaybedenlerden oldu. Derken Allah, kardeşinin cesedini nasıl gömeceğini ona göstermek için yeri eşeleyen bir karga gönderdi. (Katil kardeş) 'Yazıklar olsun bana! Şu karga kadar da mı olamadım ki kardeşimin cesedini gömeyim!' dedi ve yaptığına pişman olanlardan oldu."

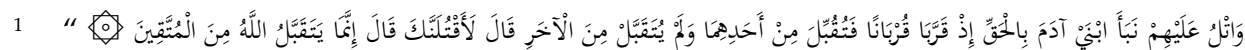

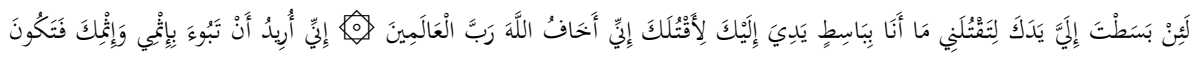

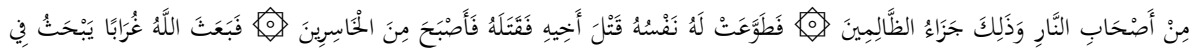

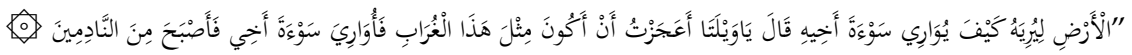


110 | Y. Emre GÖRDÜK / Klasik ve Modern Kaynaklarda Illk Cinayet Kıssası (Maide 5/27-31):

Tefsir Metodolojisi Açısından Mukayeseli Bir İnceleme

Kur'ân'da Âdem'in (a.s.) yaratılışı ve sonrası ile ilgili gayet açık âyetler bulunmaktadır. Âdem, özel bir yaratılışla ve belli safhalardan geçirilerek topraktan halk edilmiş, kendisine ruh üflenmiş ve daha sonra eşi yaratılmıştır. Bütün esmânın öğretildiği Âdem'e secde edilmesi emredilmiş ancak Melekler secde ederken şeytan bunu yapmayı reddetmiştir. $O$ ve eşi cennette sınanmış, şeytanın aldatmasıyla kendilerine yasaklanan ağaca yaklaşmış ve bu hatadan ötürü oradan çıkarılmıştır. Yaptıkları yanlışı idrâk eden ve Yüce Allah'tan bağışlanma dileyen çiftin tövbeleri makbul olmuştur. İblis Âdem'den daha hayırlı ve daha üstün olduğunu iddia ederek onun soyunu kötülüğe teşvik edip yoldan çıkarmaya yemin ederek izin istemiş; Yüce Allah da buna müsaade etmiştir. Nitekim onun ayartmaya çalışması insanoğlu için bir sınama vesilesi kılınmıştır. Ne ki İblis de isyan ve tuğyanından dolayı sonunda cehenneme atılacaktır. "Âdem" şahıs ismi olarak eşiyle beraber anıldığı gibi Nûh (a.s.) ile birlikte de anılmaktadır. Kezâ ondan ve eşinden bahseden âyetlerdeki zamirler ve fiil kipleri sürekli ikil formdadır. Irk ile övünmenin yanlışlığı ve üstünlüğün takvada oluşu, tüm insanların bir erkek ve bir dişiden halk edildiği, yani ortak atada birleştiği beyan edilerek teyit edilmektedir. ${ }^{2} \mathrm{Bu}$ tür örnekleri çoğaltmak mümkündür.

Günümüzde Hz. Âdem ve eşinin özel bir yaratılışla var edilen ilk iki insan olmadığını savunan bir yaklaşımın giderek yaygınlaştığ görülmektedir. Buna göre Kur'ân'da Hz. Âdem'in yaratılışıyla ve sonraki hayat safahatıyla ilgili âyetler semboliktir. Yeryüzünde insan altı bir tür primat zaman içinde geçirdiği evrim sonucu bugünkü insan olarak karşımıza çıkmış; belli bir gelişim ve evrim sürecinden sonrakiler "Âdem" ismiyle/sıfatıyla anılmıştır. Dolayısıyla âyetlerde Âdem diye anılan kişi bir anne ve babanın oğludur, çünkü ilk insan değildir.

Bahis mevzuu edeceğimiz kıssa bu açıdan önem arz etmektedir. Çünkü âyete göre söz konusu cinayeti işleyen kardeş, ortada duran cesedi ne yapması gerektiği konusunda şaşırıp kalmıştır. Olayın verdiği şaşkınlığın ardından âyetin beyanıyla "ona göstermek için" gönderilen bir karganın rehberliğiyle ceset defnedilmiştir. Yani sarîh nas, kargadan

2 Bk. el-Bakara 2/30-38; Âl-i İmrân 3/33; el-A'râf 7/11-25; el-Hicr 15/26-33; el-İsrâ 17/6165; el-Kehf 18/50; Tâhâ 20/115-123; Sâd 38/71-83; el-Hucurât 49/13. 
Y. Emre GÖRDÜK / The Story of the First Murder (Surah al-Maidah/27-31) in Classic and Modern Sources: A Comparative Examination in Terms of Tafsir Methodology I 111 ders alarak ölü bir insan bedeninin ne yapılması gerektiğini öğrenen katil kardeşten bahsetmektedir. Bu anlatım Hz. Âdem'le ilgili genel kabul ve perspektife uygundur. Nitekim yeryüzündeki ilk insan çiftinin çocukları, daha önce herhangi bir insanın cesedini görmemiştir. Muhtemelen biri diğerini öldüren hayvanları gördükleri için bir canlının diğerini öldürebileceğini öğrenen katil kardeşin hesaba katmadığı şey ölü bedeni ne yapması gerektiğidir. Sayısı birkaçı geçmeyen bazı müfessirler, âyetlerde örnek verilen iki kişinin Hz. Âdem'in çocukları değil İsrâiloğulları'ndan iki kişi olduğu şeklinde bir yorumu benimsemiştir. Oysa bu yoruma göre, "Katil kardeş şayet İsrâiloğulları'ndan olsa, ölü bir bedenin toprağa gömüleceğini bilmez miydi?" sorusu akla gelmektedir. Bu noktada kıssanın aksi yöndeki delâletinin oldukça güçlü olduğu görülmektedir.

Makalede yapılacak olan analizle, bir yandan yukarıda çerçevesini çizmeye çalıştığımız konuya mercek tutulmaya çalışılacak, diğer yandan müfessirlerin bu âyetleri yorumlarken hangi temel dinamiklerden ve hangi metodolojiyle hareket ettikleri tespit edilmeye çalışılacaktır. En kadîm kaynaklardan başlamak üzere klasik rivâyet ve dirâyet ağırlıklı tefsirlerde; 19. ve 20. yüzyıllarda telif edilen meşhur tefsirlerde kıssaya dâir ne tür bilgiler verilip yorumlar yapıldığ 1 incelenecektir. Ayrıca bazı çağdaş araştırmacıların ortaya koyduğu izah ve açıklamaların nasıl bir düzleme oturduğu ve hangi paradigma üzerinde yükseldiği tahlil edilecek; elimizdeki verilerin neye tekâbül ettiği tespit edilmeye çalışılacaktır. Hz. Âdem'le ilgili akademik çalışmalarda bu âyetlere değinilmişse de daha önce bu âyetler özelinde müstakil bir çalışmanın yapılmadığı görülmektedir. Çalışmaya konu olan kıssanın tamamının bütün detaylarıyla incelenmesi bir makale boyutunu fazlasıyla aşacaktır. Bu bakımdan daha ziyâde kıssada bahsi geçen iki kişinin kim olduğu ve karganın yaptığı rehberliğin ne ifade ettiği noktaları üzerinde durulacaktır. Kaynak tarama yöntemiyle elde edilen verilerin mukayeseli analizi makalede belirleyici unsur olacaktır.

Tefsirlerin tümüyle rivâyet yahut tümüyle dirâyet metoduyla telif edilmediği bilinmektedir. İstisna kabilinden İbn Ebî Hâtim'in Tefsîru'l-Kur'âni'l-Azîm'inde ve Suyûtî'nin ed-Dürrü'l-Mensûr'unda dirâyetin olmadığı söylenir ancak bunlarda bile rivâyetlerin aktarımındaki sıralama, müfessirlerin tercihleri konusunda bir fikir vermektedir. Dolayısıyla aşağıda yer alacak 2. ve 3. başlıklarda rivâyet 
112 | Y. Emre GÖRDÜK / Klasik ve Modern Kaynaklarda Illk Cinayet Kıssası (Maide 5/27-31):

Tefsir Metodolojisi Açısından Mukayeseli Bir İnceleme

ağırlıklı ve dirâyet ağırlıklı tefsirler şeklinde bir tasnife gidilecek; bu arada rivâyet ve dirâyet metotlarının aynı ölçüde kullanıldığı var sayılan en-Nüket ve'l-'Uyûn dirâyet ağırlıklı tefsirler başlığı altında mütalaa edilecektir. Tefsir kaynaklarının esas alınacağı çalışmada, konuya ilişkin rivâyet ve yorumlar içeren diğer bazı kaynaklara da yer verilecektir.

\section{Taberî Öncesi Kaynaklarda İlk Cinayet Kıssası}

En meşhûr, en kapsamlı ve kadîm rivâyet tefsiri olan Taberî'nin Câmi'u'l-Beyân'ına geçmeden önce zaman bakımından ondan evvelki ulemânın izah ve kayıtlarına kısaca değinmek faydalı olacaktır. Böylece elimizde bulunan, bize intikal eden kaynaklar açısından ilk günden bugüne kadar yapılan analiz ve yorumlara, bunun yanında fikrî ve ideolojik evrilmeye ana hatlarıyla fakat daha geniş bir perspektifle bakılmış olacaktır.

Mücâhid (öl. 104/722) âyette bahsi geçen iki kişinin Hâbil ve Kâbil olduğunu belirtmektedir. İlki kurban olarak koyun, ikincisi bakla sunmuştur. Karga, ölü olan ikinci kargayı gömmek için gönderilmiştir. ${ }^{3}$

Mukâtil b. Süleyman (öl. 150/767) Kâbil ile aynı batında doğan kız kardeşin İklîma, Hâbil ile doğanın Liyûza olduğunu söyler. Hâbil kardeşine yaptığı nasihatın sonunda, "Şayet beni öldürürsen; babamın zürriyetinden bedbahtlığına hükmedilen ve cehenneme sürüklenecek olan ilk kişi sen olacaksın." demiştir. Nihayet bir taşın sivri ucuyla Hâbil'in kafasına vuran kardeşi onu katletmiştir. ${ }^{4}$ Mukâtil diğer bir âyet (Fussilet 41/29) münâsebetiyle yine konuya değinerek yeryüzünde masiyeti ikâme eden ilk iki kişinin cinlerden İblîs, insanlardan ise Hâbil'in kâtili olan Kâbil olduğunu; Şûrâ sûresi tefsirinin sonunda ise Hâbil'in "Seyyidü'ş-şühedâ: Şehitlerin Efendisi" olduğunu söylemektedir. ${ }^{5}$

Aynı minvâlde izâhat yapan Abdürrezzâk es-San'ânî (öl. 211/826) "Âdem'in iki oğlu bu ümmete misâl olarak verilmiştir. Siz hayırl olanın

3 Mücâhid b. Cebr, Tefsîru Mücâhid, thk. Mahmud Abdüsselam Ebû'n-Nîl (Mısır: Dâru'l-Fikri'l-İslâmiyyi'l-Hadîse, 1989), 306.

4 Mukâtil b. Süleyman, Tefsîru Mukâtil b. Süleyman, thk. Abdullah Mahmud Şehâte (Beyrut: Dâru İhyai't-Türâs, 2001), 1/469-471.

5 Mukâtil b. Süleyman, Tefsîr, 3/742, 777. 
Y. Emre GÖRDÜK / The Story of the First Murder (Surah al-Maidah/27-31) in Classic and Modern Sources: A Comparative Examination in Terms of Tafsir Methodology I 113 yolunu seçin." şeklinde bir hadîsi nakletmektedir. ${ }^{6}$ Nu'aym b. Hammâd el-Mervezî (öl. 228/843) ise, Ebû Zerr Abdurrahman b. Fedâle'ye müsteniden "Kâbil Hâbil'i öldürünce, Allah onun akıl melekesini ve hafizasını aldı. Ölünceye kadar şaşkın bir vaziyette dolanıp durdu." şeklinde bir haberi kaydeder.7

İbn Sa'd (öl. 230/845) söz konusu âyetleri zikrederek yaptı̆̆1 detaylı açıklamada iki kardeşin kurbanlarını sunmak üzere Hz. Âdem'le birlikte bir tepenin üzerine çıktığını; Kâbil'in kendi kendine, "Kurbanımın kabul edilip edilmemesi umurumda değil. Hâbil benim kız kardeşimle asla evlenmeyecek!" dediğini rivâyet eder. Hâbil'in kurbanı kabul edilince içindeki hasede yenik düşen Kâbil onu öldürmüştür. Maktûl kardeşin ona "Benim günahımı da kendi günahını da yüklenirsin" demesi, bu cinayetin günahının cinayeti işlemeden önceki günahlarına ekleneceği anlamındadır. Ardından bir karga, ölmüş olan hemcinsini defnetmeye gelmiştir. ${ }^{8}$

Humeydî (öl. 219/834), İbn Ebî Şeybe (öl. 235/849), Mervezî (öl. 292/905), Ahmed b. Hanbel (öl. 241/855), Buhârî (öl. 256/870), Müslim (öl. 261/875), İbn Mâce (öl. 273/887), Tirmizî (öl. 273/892), Nesâî (öl. 303/915) gibi muhaddislere ait sahîh kaynaklarda ve burada zikretmediğimiz birçok hadîs külliyâtında yer alan hadîste Mesrûk b. Ecda', Abdullah b. Mes'ûd'dan nakille Hz. Peygamber'in (s.a.s.), "Zulmen öldürülen hiç kimse yoktur ki, onun kanından Âdem'in ilk oğluna da bir hisse çıkmasın. Çünkü öldürme (cinayet) yolunu ilk açan odur." ${ }^{9}$

6 Abdürrezzak es-San'ânî, Tefsîru Abdirrezzak, thk. Mahmud Muhammed Abduh (Beyrut: Dâru'l-Kütübi'l-i̇lmiyye, 1998), 2/15.

7 Ebû Abdillah Nu'aym b. Hammâd el-Mervezî, Kitâbu'l-fiten, thk. Semîr Emin ezZüheyrî (Kâhire: Mektebetü't-Tevhîd, 1991), 1/65, 185.

8 Ebû Abdillah Muhammed İbn Sa'd, et-Tabakâtǘl-Kübrâ, thk. Muhammed Abdülkadir 'Atâ (Beyrut: Dâru'1-Kütübi'l-İlmiyye, 1990), 1/31-32.

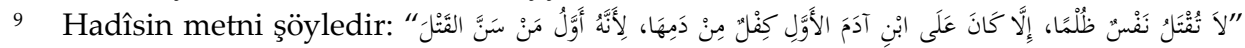
Bk. Ebû Bekir Abdullah b. ez-Zübeyr el-Kureşî el-Humeydî, Müsnedu'l-Humeydî, thk. Hasan Selim Esed ed-Dârânî (Dımaşk: Dâru's-Sekâ, 1996), 1/218; Nu'aym b. Hammâd el-Mervezî, Kitâbu'l-fiten, 1/175; Ebû Bekir Abdullah İbn Ebî Şeybe, Müsned, thk. Yûsuf el-Azâzî - Ahmed b. Ferîd el-Mezîdî (Riyad: Dâru'l-Vatan, 1992), 1/170; Ebu Abdillah Ahmed b. Hanbel, Müsned, thk. Şuayb el-Arnaût vd. (Beyrut: Müessesetü'r-Risale, 2001), 6/136; 7/170, 193; Ebû Abdullah İsmail b. İbrahim el-Cu'fî 
114 | Y. Emre GÖRDÜK / Klasik ve Modern Kaynaklarda Illk Cinayet Kıssası (Maide 5/27-31):

Tefsir Metodolojisi Açısından Mukayeseli Bir İnceleme

buyurduğunu aktarmaktadır. Aynı rivâyet farklı kelimelerle de aktarılmıştır.

Bunlar ve benzeri rivâyetler kıssada bahsedilen çocukların Hz. Âdem'in oğulları olduğunu müttefiken teyit etmektedir. Örnekleri çoğaltmak mümkündür ancak bu kadarıyla iktifâ ediyoruz.

\section{Rivâyet Ağırlıklı Klasik Tefsîrlerde İlk Cinayet Kıssası}

Taberî (öl. 310/922) âyetin muhataplarının, ellerini şer niyetle Hz. Peygamber'e (s.a.s.) ve ashâba uzatan Yahudiler olduğunu belirtir. Müellif kıssada söz konusu edilen iki kardeşin Hz. Âdem'in oğulları Hâbil ve Kâbil olduğuna dâir ekseriyeti İbn Abbâs, Mücâhid ve Katâde'den gelen, öz itibariyle aynı olan on beş rivâyet aktarmıştır. Bunlara göre Hz. Âdem Hâbil'e Kâbil'in ikiziyle, Kâbil'e Hâbil'in ikiziyle evlenmesini emretmiştir. Hâbil emre uymuş ancak Kâbil başkaldırmıştır. Ona göre kendisi ve ikizi daha üstündür ve ikisi birbirine layıktır. Hz. Âdem onun kendisine helâl olmadığını söylediyse de Kâbil bunu kabul etmemiştir. Bunun üzerine babaları, ikisine de kurban sunmaların, hangisininki kabul olursa onun haklı olduğunu söylemiştir. Bu şekilde bir nevi ilâhî mesajla Hz. Âdem'in sözü teyit edilmiş olacaktır. Yüce Allah'ın razı olup kabul ettiği kurban gönderilecek bir ateşle yakılacak, makbul olmayanı ise kuşlar yahut yırtıcı hayvanlar tarafindan yenilecektir. Neticede birinin Allah'a sunduğu kurban kabul edilmiştir. Zira çoban/besici olan Hâbil malının en kıymetlisini takdim ederken çiftçi olan Kâbil sıradan bir ürününü yahut mahsulünün en kötüsünü feda edebilmiştir. Sunulan kurbanların koyun, koç, sığır yahut dana; ekin, hububat, bakla, buğday yahut başaklı

el-Buhârî, Sahîh, thk. Muhammed Hüseyin b. Nâsır en-Nâsır (Beyrut: Dâru Tavki'nNecât, 2002), "Ehâdîsu'l-Enbiya", 1 (No. 3335); Ebü'l-Hüseyn Müslim b. el-Haccâc Müslim, Sahihu Müslim (Beyrut: Daru İhyai't-Turasi'l-Arabi), "Kasâme ve'lMuhâribîn", 27; Ebû Abdullah Muhammed b. Yezid er-Rebeî el-Kazvinî İbn Mâce, Sünen, thk. Muhammed Fuâd Abdülbaki (Beyrut: Dâru İhyai'l-Kütübi'l-Arabiyye, ts.), "Diyât", 1 (No. 2616); Ebû İsa Muhammed b. İsa es-Sevre et-Tirmizî, el-Câmiu'sSahîh (Sünenü Tirmizî) (Mısır: Şeriketü'l Mektebe ve Matbaati Mustafa el-Bâbî'lHalebî, 1975), "İlim", 14 (No. 2673); İmam Ebû Abdirrahman Ahmed b. Şuayb enNesâî, Sünen, thk. Abdülğaffar Süleyman el-Bendârî - Seyyid Küsrevî Hasan (Beyrut: Dâru'l-Kütübi'l-i̇lmiyye, 1991), “Tahrîmü'd-Dem”, 1 (No. 3985). 
Y. Emre GÖRDÜK / The Story of the First Murder (Surah al-Maidah/27-31) in Classic and Modern Sources: A Comparative Examination in Terms of Tafsir Methodology I 115 ve habbeli diğer bir tür olduğu, bahsi geçen rivâyetlerde aktarılan bilgiler arasındadır. ${ }^{10}$

Başta İbn Abbâs ve İbn Mes'ûd olmak üzere sahâbenin birçoğundan nakledildiği söylenen habere göre; Hz. Âdem'in çocukları, her batında bir kız ve bir erkek olmak üzere ikiz doğuyordu. Bir batında doğan erkek ancak diğer bir batında doğan kızla evlenebilirdi, aksi haram kılınmıştı. Çiftçi olan Kâbil yaşça sürü sahibi olan Hâbil'den büyüktü. Kâbil aynı batında doğduğu kız kardeşine kendisinin daha layık olduğu gerekçesiyle Hâbil'in onunla evlenmesini kabul etmemişti. Hz. Âdem bir gün onların yanlarından bir süreliğine ayrıldı ve ayrılırken Hâbil'i Kâbil'e emanet etti. O yokken iki kardeş kurban takdim etmişti. Hâbil besili bir dana sunarken, Kâbil bir demet başak sunmuş fakat içinde gözüne kestirdiği en irisinin tanelerini kabuklarından ayırarak yine kendisi yemişti. Neticede Hâbil'in sunduğu kurban makbûl oldu. ${ }^{11}$

Hasan el-Basrî́ye (öl. 110/728) isnâden zikredilen ikinci görüş, bahsedilen iki kişinin Hz. Âdem'in sulbünden oğulları değil zürriyyetinden gelen ve dolayısıyla oğulları sayılan İsrâiloğulları'ndan iki kişi olduğu yönündedir. Nitekim kurban İsrâiloğulları'nda vardır ve yeryüzünde ilk vefat eden kişi Hz. Âdem'dir. Taberî bunu aktardıktan sonra kesin bir dille ilk görüşü kabul ettiğini belirtir. Bahis mevzuu iki kardeş Hz. Âdem'in oğulları Hâbil ve Kâbil'dir. Ona göre bütün tefsir, ahbâr/hadîs ve siyer ehli ulemâ bu konuda icmâ' etmiştir. Yüce Allah ise muhataplara faydalı olmayan ifadelerden münezzehtir. Elbette ki her muhatap, Allah'a kurban sunma hadisesinin meleklere, şeytanlara veya sair mahlûkata değil Âdemoğullarına mahsus bir ibadet olduğunu bilmektedir. Hal böyle olunca, bahsi geçen iki kişi şayet Hz. Âdem'in oğulları olmasa, bunun özel bir vurguyla âyette zikredilmesi faydasız olacaktır. ${ }^{12}$

Kıssada geçen "müttakî" lafzı, tefsir ehlinin çoğunluğuna göre şirkten korunan; Allah'tan korkan, farzları yerine getirip seyyiattan

10 Ebû Ca'fer Muhammed b. Cerîr et-Taberî, Câmi'u'l-beyân fî te'vîli'l-Kur'ân, thk. Ahmed Muhammed Şakir (Beyrut: Müesseset'r-Risâle, 2000), 10/201-208.

11 Taberî, Câmi 'u'l-beyân, 10/206-207.

12 Taberî, Câmi 'u'l-beyân, 10/208-209. 
116 | Y. Emre GÖRDÜK / Klasik ve Modern Kaynaklarda Illk Cinayet Kıssası (Maide 5/27-31):

Tefsir Metodolojisi Açısından Mukayeseli Bir İnceleme

kaçınan ve yaptığı ibadeti halis bir şekilde Allah rızası için yapan kimse anlamındadır. Kuşkusuz ki böyle kimselerin kurbanı makbul olacaktır. ${ }^{13}$ Kimilerine göre öldürülen kardeşin kendisine saldırılsa bile karşılık vermeyeceğini söylemesi, öldürmeye teşebbüsün haram olduğunu belirtme sadedindedir. Bazıları ise, öldürülmek istenen kişinin öldürmeye teşebbüs edene karşı koymamasının, onların üzerine farz kılınmış olduğunu söylemiştir. Taberî bu iki görüşün ilkini tercih eder. Belirtilen şey katlin haram kılınmış olduğudur. Âyette ise olayın nasıl geliştiğine ve maktulün savunma yapmadiğına delâlet eden bir unsur bulunmamaktadır. Bazıları katilin suikastle aniden, hatta kardeşi uyurken başına taşla vurmak suretiyle bu cinayeti işlediğini söylemiştir. Son tahlilde âyetlerde bu hususlara 1şık tutacak delil bulunmamaktadır. ${ }^{14}$ Maktûl kardeşin "Kuşkusuz isterim ki hem benim günahımı hem de kendi günahını yüklenip ateşe atılacaklardan olasın" demesi, "Eğer beni öldürecek olursan" böyle olmanı isterim anlamindadir. ${ }^{15}$

Taberî bu kıssa sadedinde, Buhârî ve Müslim başta olmak üzere pek çok sahîh hadîs kaynağında yer alan ve makalenin ilk bölümünde zikrettiğimiz rivâyeti kaydeder. Hadîsin iki farklı rivâyetine daha işaret eden müellif; bunlara ve zikrettiği diğer haberlere istinaden Hasan elBasrî̀ye izâfe edilen görüşün yanlışlı̆̆ını bir defa daha vurgular. Nitekim Hz. Peygamber Âdemoğulları içinde cinayet yolunu ilk açan şahıstan bahsetmektedir. Bu da kâtil ve maktûlün İsrâiloğulları'ndan olmadığını göstermektedir. Çünkü öldürme hadisesi onlardan evvel vardı ve bilinmekteydi. ${ }^{16}$ Ayrıca karganın kâtil kardeşe defnetmeyi göstermesi de Hasan el-Basrî́den aktarılan haberin doğru olmadığının delillerinden biridir. Çünkü şayet bu kardeşler İsrâiloğulları'ndan iki kişi olsa, ölen birinin defnedileceğini elbette bilirdi. Bu da onların $\mathrm{Hz}$. Âdem'in çocukları olduğunu göstermektedir. ${ }^{17}$

13 Taberî, Câmi 'u'l-beyân, 10/209-212.

14 Taberî, Camiu'l-beyân, 10/213-214.

15 Taberî, Camiu'l-beyân, 10/217.

16 Taberî, Câmi 'u'l-beyân, 10/218-220.

17 Taberî, Câmi 'u'l-beyân, 10/224. 
Y. Emre GÖRDÜK / The Story of the First Murder (Surah al-Maidah/27-31) in Classic and Modern Sources: A Comparative Examination in Terms of Tafsir Methodology I 117

Bazı rivâyetlerde kâtilin, cesedi bir müddet omuzunda taşıdığı söylenmiştir. Kokmaya başlayınca Allah Teâlâ ölülerin ne yapılması gerektiğine dair usûlü öğretmeyi dilemiş ve ona iki kargayı göndermiştir. Nitekim İbn Abbâs'tan ve ashâbın diğerlerinden, iki kargadan birinin diğerini öldürdüğü ve öldüren karganın toprağ eşeleyerek onu gömdüğü aktarılmıştır. Kâtil böylece cesedin nasıl defnedileceğini öğrenmiştir. Bundan farklı olarak bazı rivâyetlerde iki karganın beraber toprağı eşelediğinden ve ölmüş olan bir kargayı defnetmesi için diğer bir karganın gönderildiğinden de bahsedilmektedir. Bütün rivâyetlerde iki karga vurgusu ortaktır. ${ }^{18}$ Kanaatimizce âyetin lafzına en uygun yorum, ölü bir kargayı defnetmesi için başka bir karganın gönderilmiş olmasıdır. Çünkü gönderildiği beyan edilen "غُرًاب: karga" lafzı tekildir.

Taberî'nin çağdaşı olan İbn Ebî Hâtim'in (öl. 327/939) tefsirinde Mâide sûresi 40. âyetten başlamaktadır ve bu âyetlerle ilgili kısım maalesef eksiktir. Ancak Yûnus sûresi 19. âyetin tefsirinde Mücâhid'den, "İnsanlar ancak tek bir ümmetti fakat Hz. Âdem'in iki oğlundan biri diğerini öldürünce ayrıldılar." şeklinde bir rivâyete yer vermiştir. ${ }^{19}$

Semerkandî (öl. 373/973) Kutebî'den naklen kıssanın sonunda geçen "pişman olanlardan oldu" ifadesinin, karga gönderilene kadar cesedin ortada kalması yahut Kâbil'in onu beraberinde taşıması durumuna ilişkin olduğunu belirtir. İbn Abbâs bunu teyiden "Şâyet onun pişmanlığı işlediği cinayetle ilgili olsaydı, bu onun hakkında tövbe olurdu." demiştir. Hz. Âdem'in cinayet yolunu ilk açan çocuğuyla ilgili hadîsi de zikreden müellif, bunların İsrâiloğulları arasından iki kişi olduğu görüşünün müfessirlerin kavline muhalif olduğunu kaydetmiştir. ${ }^{20}$

Sa'lebî’nin (öl. 427/1036) farklı olarak dikkat çektiği bilgiye göre, Kâbil evlenme konusundaki emrin Allah'tan geldiğini kabul etmeyip onun Hz. Âdem'in görüşü olduğunu iddia etmiştir. Başka bir insanı

18 Taberî, Camiu'l-beyân, 10/225-229.

19 Ebû Muhammed Abdurrahman b. Muhammed İbn Ebî Hâtim, Tefsîru'l-Kur'âni'l'Azîm, thk. Es‘ad Muhammed Tayyib (Suudi Arabistan: Mektebetü Nizâr, 1998), 6/1937.

20 Ebu'l-Leys es-Semerkandî, Bahru'l- 'Ulûm (b.y.: y.y., ts.), 1/383-385. 
118 | Y. Emre GÖRDÜK / Klasik ve Modern Kaynaklarda Illk Cinayet Kıssası (Maide 5/27-31):

Tefsir Metodolojisi Açısından Mukayeseli Bir İnceleme

öldürmeyi ise İblîs'ten öğrendiği aktarılmıştır. Müellifin Hz. Âdem'in oğullarının cinler ve hûrîlerle evlendiğine dâir İmam Ca'fer es-Sâdık'a (öl. 148/765) isnâden zikredilen tuhaf bir rivâyeti de aktardığ1 görülmektedir. ${ }^{21} \mathrm{Bu}$ rivâyetin asılsız olduğu belirtilmiştir. ${ }^{22}$ Anlaşılan o ki âsi evlat yanlış yolda olduğunu gözüyle görsün ve ikna olsun diye Hz. Âdem onlara kurban sunmalarını emretmiştir. Kanaatimizce onun bu tavrından, babasının nübüvvetini inkâr ettiği sonucu çıkarılabilir. Çünkü emrini dinlememekte, sözüne güvenmemektedir. Sa‘lebî’den on yıl sonra vefat eden Mekkî b. Ebî Tâlib (öl. 437/1045), rivâyetleri sıraladığ1 tefsirinde herhangi bir değerlendirmede bulunmamıştır. ${ }^{23}$ Sem'ânî'nin (öl. 489/1095) aktarımları ise genel çerçevede Hâbil-Kâbil vurgusuyladır. ${ }^{24}$

Beğavî (öl. 516/1122) konuyu ele alırken, Kâbil'in Hâbil'i öldürmeye niyet ettiğini, fakat Hz. Âdem'in Mekke'ye Beyt'i ziyâret etmeye gitmesini beklediğini kaydeder. Abdullah b. Ömer'den nakledildiğine göre $\mathrm{Hz}$. Âdem'in şeriatında öldürmeye niyet eden kimseye karşı, -tıpkı Hz. Osman'ın da yaptığı gibi- ecrini Allah'tan bekleyerek boyun eğip teslim olmak câizdi. Mücâhid'den yapılan rivâyete göreyse, öldürme niyetiyle saldırana karşılık vermeyip sabretmeleri onların şeriatında farz kılınmıştır. ${ }^{25}$

İbn 'Atıyye (öl. 541/1147) cumhur-1 müfessirîne göre bahsi geçen iki kişinin Hâbil ve Kâbil olduğunu belirtir. Ona göre aksini düşünmek vehimden ibarettir. İsrâiloğulları'ndan olan bir şahsın ölü defnetmeyi

21 Ebû İshak Ahmed b. Muhammed b. İbrahim es-Sa' lebî, el-Keşf ve'l-Beyan an Tefsîri'lKur'ân, thk. Ebû Muhammed b. Âşûr (Beyrut: Dâru İhyai't-Türâsi'l-Arabî, 2002), 4/48-53.

22 İbn Hacer el-'Askalânî, Fethü'l-Bârî alâ Sahîhi'l-Buhârî (Beyrut: Dâru'l-Ma'rife, 1959), $6 / 369$.

23 Ebû Muhammed Mekkî b. Ebî Talib, el-Hidâye ilâ bulûği'n-nihâye fî̀ İlmi me 'âni'l-Kur'ân ve Tefsîrihi, thk. Heyet (Birleşik Arap Emirlikleri: Câmiatu'ş-Şârika/Külliyetü'ş-Şeria ve'd-Dirâsâti'l-İslâmiyye, 2008), 3/1675-1686.

24 Ebu'l-Muzaffer Mansur b. Muhammed Sem'ânî, Tefsîru'l-Kur'ân, thk. Yâsir b. İbrâhim - Ğanîm b. Abbâs b. Ğanîm (Riyad: Dâru'l-Vatan, 1997), 2/29-32.

25 Ebû Muhammed el-Hüseyin b. Mes'ûd b. Muhammed b. el-Ferrâ el-Beğavî, Me'âlimu't-Tenzîl fî Tefsîri'l-Kur'ân, thk. Abdürrezzak el-Mehdî (Beyrut: Dâru İhyai'tTürâsi'l-Arabî, 1998), 3/41-45. 
Y. Emre GÖRDÜK / The Story of the First Murder (Surah al-Maidah/27-31) in Classic and Modern Sources: A Comparative Examination in Terms of Tafsir Methodology I 119 bilmemesi olanaksızdır. Saldırana karşılık verilmemesi hakkında Beğavî gibi Hz. Osman örneğini veren müellif, Ehl-i Sünnet'in icmâryla "müttakî" lafzının başta şirkten kaçınan kimse anlamında olduğunu söyler. Zira muvahhid olan kimse amelini Allah için yapacak ve niyeti de sağlam olacaktır. Âyetlerdeki hitap Yahudileredir, çünkü onlar Hz. Peygamber'i (s.a.s.) öldürmek için teşebbüs eden kimselerdir. Bu misâlin verilmesi, Tevrat'ta da geçen ${ }^{26}$ olayı onlara ihtar etmektir. ${ }^{27}$ Kâbil'in kâfir olup olmadiğ 1 konusunda ihtilaf olduğunu belirten İ̉n 'Atıyye, onun âsî ve günahkâr olduğu kanaatindedir. Bu kanaatini, "Muhakkak ki Allah size Âdem'in iki oğlunu misâl olarak vermiştir. O halde siz hayırlı olanın yolunu takip edip şerri terk edin." şeklindeki hadîse bağlar. ${ }^{28}$

İbn Kesîr de (öl. 774/1328) tıpkı İbn 'Atıyye gibi cumhurun görüşünü vurgulayıp farklı âlimlerden gelen rivâyetleri uzun uzun aktarırken, selef ve haleften sadece bir kişi haricinde herkesin iki kardeş hakkında Hâbil-Kâbil ekseninde açıklama yaptığını birkaç kere hatırlatmaktadır. İlk ayetteki "باِلِّْق lafzına özel vurgu yapan ve başka âyetlerden de örnekler veren müellif anlatılan hadiste de asla şek ve şüphe bulunmadığının altını çizer. Hz. Âdem, eşi ve onların çocuklarından oluşan ilk insan topluluğunun tabiatıyla farklı bir şeriata tabi olduğuna dikkat çeker; diğer müfessirler gibi kıyamete kadar işlenecek cinayetlerden ilk katli yapan insanın hissedar olduğunu belirten hadîsi ve bu minvâlde başka haberleri nakleder. İbn Kesîr kıssanın Hz. Âdem'in iki oğlundan bahsettiği hususunda ittifak olduğuna, bunun âyetin zâhiriyle ve hadîslerle sâbit olduğuna, Hasan

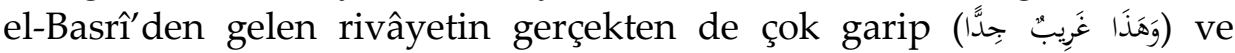
isnadının şüpheli olduğuna vurgu yaparak aksi yöndeki birçok rivâyeti zikretmektedir. ${ }^{29}$

26 Kutsal Kitap (Tevrat, Zebur, İncil) (İstanbul: Kitab-1 Mukaddes Şirketi/Yeni Yaşam Yayınları, 2010), Yaratılış 4/1-15.

27 Ebû Muhammed Abdülhak b. Galib İbn 'Atıyye, el-Muharreru'l-vecîz fî tefsîri'lKitâbi'l-'Azîz, thk. Abdüsselam Abdüşşafî Muhammed (Beyrut: Dâru'l-Kütübi'lİlmiyye, 2000), 2/178-179.

28 İbn 'Atyyye, el-Muharrer, 6/2/181.

29 Ebû'l-Fidâ İsmail b. Ömer el-Kureşî İbn Kesîr, Tefsîru'l-Kur'âni'l-Azîm, thk. Sami b. Muhammed Selâme (Misır: Dâru't-Taybe, 1999), 3/81-91. 
120 | Y. Emre GÖRDÜK / Klasik ve Modern Kaynaklarda Illk Cinayet Kıssası (Maide 5/27-31):

Tefsir Metodolojisi Açısından Mukayeseli Bir İnceleme

Se'âlibî (öl. 875/1470) âyetin zâhirine göre Âdemoğullarından ilk ölenin Hâbil olduğunu söyler. Bundan dolayı Kâbil cesedin üzerini toprakla örtmeyi bilememiştir. Müellif, Taberî'nin bunu İbn İshâk'ın Ehl-i Kitap alimlerinden yaptığı nakle dayanarak aktardığını belirtir. ${ }^{30}$ Buradaki atıf Taberî'nin Tefsîr' ine değil Târih'inedir. ${ }^{31}$

Konuyla ilgili pek çok rivâyeti bir araya getiren ancak kendi görüşüne yer vermeyen Suyûtî'nin (öl. 911/1505), sıhhat dereceleri muhtelif olan nakillerinin ortak noktası, bahsi geçen iki kişinin $\mathrm{Hz}$. Âdem'in iki oğlu olduğu eksenindedir. Müellif Hasan el-Basrî́ye izâfe edilen görüşe de yer vermiştir. ${ }^{32}$

Zamanca bize en yakın olan müfessirlerden Kâsımî (öl. 1332/1914) tefsirinde ilgili hadîsleri ve sahâbe sözlerini zikretmekte, diğer haberleri ve bazı müfessirlerin görüşlerini özetlemektedir. Sa'd b. Ebî Vakkas'tan nakledilen "Dedim ki 'Ya Resûlallah, biri evime girse ve beni öldürmek için elini uzatsa ne dersiniz?'. Bana cevaben 'Âdem'in oğlu gibi ol!'

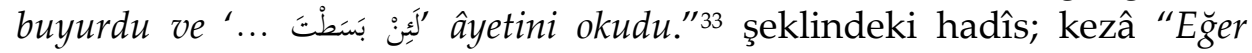
yapabilirsen Allah'ın maktûl bir kulu ol ama kâtil bir kulu olma!"34 hadîsi, diğer bazı hadîslerle beraber müellifin kayıtları arasındadır. ${ }^{35}$ Bunlar Müslümanlar arasında çıkacak fitne durumları için verilmiş olan öğütlerdir ve nitekim Hz. Osman zamanında ortaya çıkıp devam eden olaylarda daha ziyade önem verilerek rivâyet edildikleri anlaşılmaktadır. Kâsımî, âyetin zâhirine göre kâtilin ölü kardeşinin cesedini defnetmeyi kargadan öğrendiğini belirtir. Kendisi de bu görüşte ve cumhurun çizgisindedir. ${ }^{36}$

30 Ebû Zeyd Abdurrahman b. Muhammed es-Se'âlibî, el-Cevâhiru'l-hisân fî tefsîri'lKur'ân, thk. Muhammed Ali Mu'avvid - Âdil Ahmed Abdülmevcûd (Beyrut: Dâru İhyai't-Türâsi'l-Arabî, 1997), 2/369-372.

31 Ebû Ca'fer Muhammed b. Cerîr et-Taberî, Târîhu'r-rusul ve'l-mülûk (Beyrut: Dâru'ttürâs, 1967), 1/139-140.

32 Celâlüddin Abdurrahman es-Suyûtî, ed-Dürrü'l-mensûr (Beyrut: Dâru'l-Fikr, ts.), 3/54-64.

33 Ahmed b. Hanbel, Müsned, 3/161; Tirmizî, Sünen, “Fiten”, 29 (No. 2194).

34 İbn Ebî Şeybe, Müsned, 1/318.

35 Muhammed Cemâlüddin b. Muhammed Sa'îd el-Kâsımî, Mehâsinü't-te'vîl (Beyrut: Dâru'l-Kütübi'l-i̇lmiyye, 1996), 4/108-110.

36 Kâsımî, Mehâsinü't-te'vîl, 4/107-114, 111. 
Y. Emre GÖRDÜK / The Story of the First Murder (Surah al-Maidah/27-31) in Classic and Modern Sources: A Comparative Examination in Terms of Tafsir Methodology I 121

$\mathrm{Bu}$ şekilde rivâyet ağırlıklı sayılan tefsirlerin en meşhurlarına kısaca değinerek; mümkün mertebe tekrara düşmemek için her müfessirin söylediklerini detaylarıyla aktarmadan, dikkat çektikleri farklı bazı noktaları kaydetmeye çalıştık. Metodolojik açıdan, rivâyet ağırlıklı tefsirlerde Hz. Peygamber'den (s.a.s.) intikal edip sahîh hadîs kaynaklarında yer alan hadîslerin, kezâ ashâb ve tabîûn ulemâsından menkûl görüşlerin aktarıldığı; ayrıca müteahhir olanların kadîm müfessirlerin görüşlerinden istifade ettiği görülmektedir. Hepsinin tartışmasız ortak noktası, bahsi geçen iki kişinin Hz. Âdem'in oğulları olduğu yönündedir. Çünkü hem âyetlerin zâhiri hem de ilgili rivâyetler bu yöndedir. Nitekim ilk muhataplar olan sahâbeden ve onların öğrencileri olan tâbiûndan bize intikal eden farklı bir haber bulunmamaktadır. Her ne kadar İslami ilimler literatüründe yer alan bütün eserleri bu makale çerçevesinde incelemiş olmasak da bunu rahatlıkla söylemek mümkündür. Cumhura muhalif sadece bir haberin intikal ettiğini bizzat müfessirlerin kendileri de teyit etmektedir. Kimileri merfû' hadîs olan onlarca güvenilir rivâyetin karşısında sadece Hasan el-Basrî'ye izâfe edilen bu rivâyet makbul addedilmemiştir.

Diğer bir noktaya dikkat çekecek olursak, Hasan el-Basrî́nin ilk yaratılan insan çiftinin Hz. Âdem ve eşi olduğu konusunda herhangi bir şüphe ve itirazının bulunmadığ 1 görülmektedir. ${ }^{37}$ Onun bu kıssa özelinde bahsedilen iki kişinin İsrâiloğulları'ndan olduğunu söylemesi, muhtemelen kelâmın siyakına göre verdiği anlamdan ibarettir. Şayet ondan gelen nakil doğruysa, konuyla ilgili sahîh hadîsleri ve sahâbenin kanaatlerini nazara almadığı anlaşılmaktadır.

\section{Dirâyet Ağırlıklı Klasik Tefsîrlerde İlk Cinayet Kıssası}

$\mathrm{Bu}$ başlık altında, dirâyet ağırlıklı tefsirlerde konunun nasıl ele alındığı tahlil edilmeye çalışılacaktır. Yine aynı usulle söz konusu kıssanın beş âyetindeki her ifâde ve lafızla ilgili değil daha ziyâde konunun ana ekseni, lafızların delâleti, bahsi geçen şahısların kimliği ve bu minvâldeki rivâyet ve görüşler hakkında yapılmış yorumlar üzerinde durulacaktır.

37 Hasan el-Basrî, Tefsîru'l-Hasani'l-Basrî, ed. Muhammed Abdürrahim (Kâhire: Dâru'lHadîs, ts.), 1/78-79. 
122 | Y. Emre GÖRDÜK / Klasik ve Modern Kaynaklarda Illk Cinayet Kıssası (Maide 5/27-31):

Tefsir Metodolojisi Açısından Mukayeseli Bir İnceleme

Taberî ile çağdaş olan İmam Mâturîdî (öl. 333/944) bahis mevzuu olan iki kişi hakkında iki farklı görüşü aktardıktan sonra doğrusunun ne olduğunun, kıssanın nasıl cereyan ettiğinin bilinemeyeceğini ve alınması gereken ilim/hikmet açısından bunun gerekmediğini söyler. Ona göre ilk âyetteki "Hakk" vurgusu ya nâzil olan âyete yahut anlatılan olayın kesinliğine ilişkindir. Kâtilin duyduğu pişmanlık ya işlediği cinayete yahut âhirette göreceği azaptan dolayı dünyadaki amelleri için duyacağı pişmanlıktır. İki kişinin Hz. Âdem'in ilk çocukları olduğunu söyleyenler, karganın yaptığı kılavuzluğu buna delil olarak kullanmaktadır. Aksini iddia edenlere göreyse kişinin daha önce görüp bildiği bir şeyi, yaşadığı korku ve dehşet içinde unutması, o şeyin aklından uçup gitmesi mümkündür. Konuyla ilgili tercihte bulunmayan müellifin ilgili hadîs ve rivâyetleri nazara almadığ1 görülmektedir. ${ }^{38}$

Mâverdî (öl. 450/1059) cumhurun görüşüne temel teşkil eden rivâyetlerin İbn Ömer, İbn Abbas, Mücâhid, Katâde gibi sahâbe ve tâbiûn âlimlerinden geldiğini belirtmiştir. ${ }^{39}$ Zeydî müfessir Hâkim elCüşemî (öl. 494/1101) bahsi geçen iki kişinin Hz. Âdem'in evlatları olduğu konusunda sahâbe ve tâbiûn ulemâsı ile birlikte Ebû Ali elCübbâî (öl. 303/916) ve Ebû Müslim el-Isfahânî'nin (öl. 322/934) de aynı kanaatte olduğunu belirtir. Hasan el-Basrî ile birlikte ise Ebû Bekir b. elAsamm'ın (öl. 200/816) adını zikreder. Fakat hem âyetin zâhiri hem de haberlerin mütevâtir olması ona göre cumhurun görüşünü desteklemektedir. ${ }^{40}$

Râgıb el-Isfahânî (öl. 502/1108) Hasan el-Basrî'den gelen görüşü zikrederek cumhurun görüşünün daha doğru olduğunu belirtmiş, bunu da ilgili hadîse bağlamıştır. ${ }^{41}$ Ebû Hafs en-Nesefî (öl. 537/1142) Hasan el-

38 Ebû Mansûr Muhammed el-Mâtürîdî, Te'vîlâtü'l-Kur'ân, thk. Mecdî Bâslûm (Beyrut: Daru'l-Kütübi'l-İlmiyye, ts.), 3/496-501.

39 Ebu'l-Hasan Ali b. Muhammed el-Mâverdî, en-Nüket ve'l-uyûn, thk. Seyyid b. Abdilmaksûd b. Abdirrahim (Beyrut: Dâru'l-Kütübi'l-i̇lmiyye, ts.), 2/27-31.

40 Ebû Sa'd el-Muhassin b. Muhammed b. Kerrâme Hâkim el-Cüşemî, et-Tehzîbu fi'ttefsîr (Kahire/Beyrut: Dâru'l-Kütübi'l-Misriyye/Dâru'l-Kütübi'l-Lübnâniyye, 2018), 3/1933-1939.

41 Râgıb el-Isfahânî, Tefsîrü'r-Râgıb el-Isfahân̂̂, thk. Hind bint Muhammed b. Zâhid Serdâr (Mekke: Camiatu Ümmi'l-Kurâ/Külliyyetü'd-Da'veti ve Usûli'd-Dîn, 2001), $4 / 324$. 
Y. Emre GÖRDÜK / The Story of the First Murder (Surah al-Maidah/27-31) in Classic and Modern Sources: A Comparative Examination in Terms of Tafsir Methodology I 123

Basrî'den gelen rivâyeti, onun "Bazı insanlar şöyle demektedir" şeklinde ortaya koyduğunu belirtmiştir. Bununla İsrâiloğulları içinde hasedin çok eskiden beri var olduğu vurgulanmış ve Yahudilerin Hz. Peygamber'e (s.a.s.) karşı sûikastlerine işaret edilmiştir. Müellife göre bu, nazma daha yakınsa da hadîs rivâyetlerine aykırıdır. ${ }^{42}$ Zemahşerî (öl. 538/1143) Hasan el-Basrî̀den gelen görüşü isim zikretmeksizin "denildi ki" lafziyla nakleder. Ona göre "Hakk" vurgusu sihhatli ve hak bir tilâvet, evvelki kitaplara muvafık hak bilgi, Yahudilerin hasetlerine karşılık hak olan amaç/gaye yahut âyetleri tebliğ eden Hz. Peygamber'in (s.a.s.) hak ve doğruluğu sadedinde zikredilmiştir. Kâtil kardeşin nedâmeti tövbe pişmanlığı değil düştüğü halden dolayıdır. ${ }^{43}$ İbnü'l-Cevzî (öl. 597/1201) iki görüşü de zikretmiş ancak cumhurun görüşünün doğru olduğunu belirtmiştir. Çünkü ilgili hadîsler bunu göstermektedir. ${ }^{44}$

Dirâyette adeta bir dönüm noktası olan Fahruddîn er-Râzî (öl. 606/1209) kıssanın bağlantısını öncelikle aynı sûrenin 11. âyetiyle kurar. Âyette "Hani bir kavim ellerini size uzatmaya yeltenmişti" 45 ifadesiyle düssmanların müminlere sûikastle hücum ettiklerini ancak Yüce Allah'ın onları bundan koruduğu anlatılmaktadır. [11. âyette bahsedilen şey Nadîroğulları'nın yahut Kureyş müşriklerinin Hz. Peygamber'i (s.a.s.) öldürme teşebbüsleridir. ${ }^{46}$ ] Daha sonra, gönderilen on iki nakîble İsrâiloğulları'ndan alınan ahit ve ardından onların bunu bozmasına değinilmiş (12-13. âyetler); gittikleri yolun yanlışlığına ilişkin kat'î deliller zuhûr ettiği halde Hristiyanların küfürde ve teslîste ısrar etmesinden bahsedilmiştir (15-17. âyetler). Bu durum onların $\mathrm{Hz}$. Peygamber'e (s.a.s.) verilen hak dinden dolayı duydukları haset sebebiyledir. Ardından Hz. Mûsa'nın (a.s.) zulümkâr müstebitlerle muharebesi ve kavminin onu yalnız bırakmadaki ısrar ve inatları söz konusu edilmiş (20-26. âyetler) ve nihayet Hz. Âdem'in (a.s.) iki

${ }^{42}$ Necmüddîn Ömer b. Muhammed Ebû Hafs en-Nesefî, et-Teysîr fi't-tefsîr, thk. Mâhir Edîb Habbûş (Beyrut: Dâru'l-Lübâb, 2019), 5/359.

43 Ebu'l-Kāsım Mahmûd b. Ömer ez-Zemahşerî, el-Keşşâf 'an hakā'iḳ ġavâmidi't-tenzîl ve 'uyûni'l-ekāôil fî vücûhi't-te 'vîl (Beyrut: Daru'l-Kitabi'l-Arabi, 1985), 1/623-626.

44 Ebu'l-Ferec Cemâlüddin Abdurrahman İbnü'l-Cevzî, Zâdu'l-mesîr fî̀ ilmi't-tefsîr, thk. Abrürrezzak el-Mehdî (Beyrut: Dâru'l-Kitâbi'l-Arabî, 2001), 1/536-539.

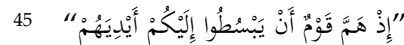

46 Bk. Mâverdî, en-Nüket, 2/19. 
124 | Y. Emre GÖRDÜK / Klasik ve Modern Kaynaklarda Illk Cinayet Kıssası (Maide 5/27-31):

Tefsir Metodolojisi Açısından Mukayeseli Bir İnceleme

oğlundan bahseden kıssaya gelinmiştir. Bütün bunlarda, verilen nimetlerden bahsedilmekte ve bunlara yönelik haset anlatılmaktadır. Hz. Peygamber'e verilen nimet öyle büyüktür ki bütün düşmanları ona karşı ittifak etmiştir. Sûrenin başından beri anlatılanlar, haset ve zulme karşı, ayrıca Yahudilerin ona kurduğu bir tuzak münasebetiyle teselli mahiyetindedir. Kıssa, Ehl-i Kitab'ın gizlediği Tevrat hükümleriyle (15. âyet); Hz. Mûsa'yı yalnız bırakan kavminin tıpkı kâtil olan kardeş gibi yaşadıkları pişmanlık ve hasaretle; Yahudiler ve Hristiyanların "Biz Allah'ın oğulları ve sevdikleriyiz" (18. âyet) demesiyle irtibatlıdır. İsrâiloğulları nasıl ki küfürleri sebebiyle, dedeleri olan birçok peygamberden Allah katında bir fayda görmediyse, cânî oğul da peygamber olan babası Hz. Âdem'den fayda görmemiştir. ${ }^{47}$

Râzî, Hasan el-Basrî ile beraber Dahhâk'ı (öl. 105/723) da

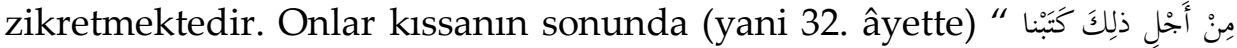
: Bundan dolayı İsrâiloğulları'na ... yazmıştık (farz kılmıştık)" buyrulmasını delil addederek anlatılan iki kişinin İsrâiloğulları'ndan iki kişi olduğunu söylemiştir. Çünkü Hz. Âdem'in oğlunun işlediği fiilden dolayı İsrâiloğulları'na kısas hükmünün konulması uygun olmaz. Ayrıca kıssa Yahudilere mahsus son derece katı ve ulaşılmaz bir haset derecesine gönderme yapmaktadır. Öyle ki bahsi geçen mücrim, başka hiçbir sebep yokken, sırf kendi kurbanı kabul edilmedi diye kurbanı kabul edilen birini öldürmüştür. Kıssa hasedin Yahudilerde kadîm bir alışkanlık olduğuna vurgu yapıyor diye düşünülünce de bahsi geçen iki kişi İsrâiloğulları'ndandır demek gerekmektedir. ${ }^{48}$ Müellif bu açıklamayı yaptıktan sonra müfessirlerin ve ulemânın ekseriyetinin bu görüşü tercih etmediğini, âyetin delâletinin de o yönde olmadığını, kâtilin cesedi ne yapacağını bilmediğini vurgulayan kısmın bunun tam aksine delâlet ettiğini söyler. Nitekim eğer kâtil İsrâiloğulları'ndan biri olsaydı cesedi ne yapması gerektiğini bilirdi. ${ }^{49}$

Kanaatimizce sûrenin 26. âyetine kadar olan bölümüyle kıssa arasında kurulan bütün bağlantılar bahsi geçen iki kişinin Hz. Âdem'in

47 Fahrüddîn Ebû Abdillah Muhammed b. Ömer er-Râzî, Mefâtîhu'l-gayb (Beyrut: Dâru İhyai't-Türâsi'1-Arabî, 1998), 11/336-337.

48 Râzî, Mefâtîh, 11/337-338.

49 Râzî, Mefâtîh, 11/338. 
Y. Emre GÖRDÜK / The Story of the First Murder (Surah al-Maidah/27-31) in Classic and Modern Sources: A Comparative Examination in Terms of Tafsir Methodology I 125 oğulları olduğunu teyit eder niteliktedir. Çünkü ilk 26 âyette Kureyş müşriklerinin sûikastlarına işaret edilmiş, Yahudi ve Hristiyanlardan ise açıkça bahsedilmiştir. Bunların hepsi İslam düşmanlığ 1 ortak paydasında birleşen topluluklardır. Dolayısıyla yaptıkları düşmanlık, izhar ettikleri kin, nefret, kıskançlık ve haset yine hepsinin birleştiği atanın ilk çocuklarından örnekle hepsini kapsayıcı bir şekilde yüzlerine vurulmaktadır. Ayrıca haset Yahudilerde karakteristik bir özellik haline gelmiş olsa bile taşıdığı potansiyel açısından insanoğlunun her bir ferdini canavarlaştırabilen bir zaaftır.

Bu arada tıpkı Hasan el-Basrî gibi Râzî'nin zikrettiği ikinci isim olan Dahhâk'ın da ilk yaratılan insan çiftinin Hz. Âdem ve eşi olduğu konusunda herhangi bir şüphe ve itiraz beyanında bulunmadığını kaydetmek gerekir. ${ }^{50}$

Kurtubî (öl. 671/1273) kıssanın anlamını şöyle özetler: Ey Muhammed (s.a.s.) şayet Yahudiler seni öldürmeye kastettiyse (şaşırma), şüphesiz ki onlar senden önce de birçok nebîyi katletmiştir; Kâbil de Hâbil'i öldürmüştür, çünkü şer kadîmdir. Onlara bu kıssayı hatırlat çünkü bu uydurulmuş sözler gibi değil şüphesiz doğru bir kıssadır. Bu anlatıda İslâm muhaliflerine azarlama Hz. Peygamber'e teselli vardır. ${ }^{51}$ Müellif, Hasan el-Basrî’ye isnat edilen görüşü belirtir ancak bu konuda İbn 'Atıyye'nin cevabını aktarır ve tasdik eder. ${ }^{52}$ Kurtubî, Ca'fer es-Sâdık'a isnat edilen, daha önce yer verdiğimiz görüşün sahîh olmadığını, çünkü Nisâ sûresinin ilk âyetindeki sarîh nassa aykırı olduğunu belirtir. Zira âyette ilk insan çiftinden birçok erkekler ve kadınlar yaratıldığı söylenmektedir. İlk nesilde her batında ikişer ikişer doğan çocukların kendi ikizleriyle evlenmeleri haram kılınmıştır. ${ }^{53}$

50 Dahhâk b. Müzâhim, Tefsîru'd-Dahhâk, ed. Muhammed Şükri Ahmed ez-Zâviyetî (Kâhire: Dâru's-Selâm, 1999), 1/151-152, 271.

51 Şemsüddîn Ebû Abdillah Muhammed b. Ahmed el-Hazrecî el-Kurtubî, el-Câmi' liahkâmi'l-Kur'ân, thk. Ahmed el-Berdûnî - İbrâhim Atfîş (Kahire: Dâru'l-Kütübi'lMisriyye, 1964), 6/133.

52 Kurtubî, el-Câmi', 6/133.

53 Kurtubî, el-Câmi', 6/135. 
126 | Y. Emre GÖRDÜK / Klasik ve Modern Kaynaklarda Illk Cinayet Kıssası (Maide 5/27-31):

Tefsir Metodolojisi Açısından Mukayeseli Bir İnceleme

Beydâvî (öl. 685/1286) konuya özel bir vurgu yapmazken genel anlamda cumhurla aynı görüştedir. ${ }^{54}$ Nesefî (öl. 710/1310) Hz. Âdem'in çocukları yahut İsrâiloğulları'ndan iki kişi diye ihtimalleri belirtir ancak onun da cumhurun görüşünü paylaştığı anlaşılmaktadır. ${ }^{55}$ Kezâ İbn Cüzey'in (öl. 741/1340) cumhur çizgisinde olduğu görülmektedir. ${ }^{56}$ Hâzin (öl. 741/1341) karganın kâtil kardeşe defin işini öğretmesine dikkat çeker. Ona göre cumhurun kanaatine sebep olan şey budur. Kendisi de aynı kanaattedir. ${ }^{57}$ Ebû Hayyân'a (öl. 741/1341) göre Hasan el-Basrî vehmetmiştir. Hem âyetin nassıyla karganın defnetme işini öğretmiş olması hem de kâtilin öldürme yolunu açan ilk insan olduğunu beyan eden hadîs buna delildir. ${ }^{58}$ İbn 'Âdil ed-Dımaşkî (öl. 775/1373-74) Râzî'nin yapmış olduğu izâhatı neredeyse birebir almış, bunun yanında kendinden önceki meşhur müfessirlerin görüşlerine de yer vererek çok ayrıntılı bilgiler vermiştir. ${ }^{59}$ Neysâbûrî (öl. 850/1447) İbn 'Âdil ile aynı mahiyette fakat daha kısa bir anlatım yapmıştır. ${ }^{60}$ Bikâ'î (öl. 885/1480) kıssanın tefsirinde genel çerçeveyi takip ederken ${ }^{61}$ Ebu's-Su'ûd (öl. 982/1574) ise Hasan el-Basrî ve Dahhâk'tan nakledilen görüşün kıssanın

54 Kâdî Nâsıruddîn Ebî Sa'îd Abdullah b. Ömer el-Beydâvî, Envârü't-tenzîl ve esrârü'tte'vîll, thk. Muhammed Abdurrahman el-Mar'aşlî (Beyrut: Daru İhyai't-Türasi'lArabî, 1997), 2/123-124.

55 Ebu'l-Berekât Abdullah b. Ahmed b. Mahmûd Hâfızuddîn en-Nesefî, Medârikü'tTenzîl ve hakâiku't-te'vîl, thk. Yusuf Ali Bedîvî (Beyrut: Dâru'l-Kelimi't-Tayyib, 1998), 1/441-442.

56 Ebu'l-Kâsım Muhammed b. Ahmed İbn Cüzey, et-Teshîl li 'ulûmi't-tenzîl, thk. Abdullah el-Hâlidî (Beyrut: Şeriketu Dâri'l-Erkam b. Ebî'l-Erkam, 1995), 1/228-229.

57 Alâuddîn Ali b. Muhammed b. İbrâhim el-Hâzin, Lübâbü't-te'vîl fî̀ me 'âni't-tenzîl, thk. Muhammed Ali Şahin (Beyrut: Dâru'l-Kütübi'l-İlmiyye, 1994), 2/32-34.

58 Esîrüddin Muhammed Yûsuf b. Ali Ebû Hayyân, el-Bahru'l-muhît fi't-tefsîr, thk. Sidkî Muhammed Cemil (Beyrut: Dâru'l-Fikr, 1999), 4/227.

59 Ebû Hafs Siracüddîn Ömer b. Ali İbn 'Âdil, el-Lübâb fî̀ 'ulûmi'l-Kitab, thk. Adil Ahmed Abdülmevcud - Ali Muhammed Mu'avvıd (Beyrut: Dâru'l-Kütübi'l-İlmiyye, 1998), 7/280-297.

60 Nizâmüddin el-Hasan b. Muhammed el-Kummî en-Neysâbûrî, Garâibu'l-Kur'ân ve reğâibu'l-Furkân, thk. Zekeriyya 'Umeyrat (Beyrut: Dâru'l-Kütübi'l-İlmiyye, 1995), 2/577-582.

61 Ebu'l-Hasan Burhanüddin İbrahim b. Ömer el-Bikâ'̂̂, Nazmu'd-dürer fî̀ tenâsübi'l-âyâti ve's-suver (Kâhire: Dâru'1-Kütübi'l-İslâmî, ts.), 6/112-125. 
Y. Emre GÖRDÜK / The Story of the First Murder (Surah al-Maidah/27-31) in Classic and Modern Sources: A Comparative Examination in Terms of Tafsir Methodology I 127 sonundaki (32. âyet) karineye göre olduğunu fakat bunun doğru olmadığını belirtmiştir. ${ }^{62}$

Bursevî (öl. 1127/1715) âyette geçen “Âdem” lafzının “Ebu'lbeşer" anlamına geldiğini özellikle vurgular. İki oğul Hâbil ile Kâbil'dir. "Derken Allah bir karga gönderdi"63 ifadesinde, Yüce Allah'ın insana bilmediği şeyi öğretmesi için kargayı ve istediği herhangi bir hayvanı göndermeye muktedir olduğuna işâret vardır. Tıpkı bilmedikleri şeyleri öğretmesi için melekleri peygamberlere, peygamberleri ümmetlere göndermesi gibi. ${ }^{64}$ Yani karga daha önce bilinmeyen bir şeyi gösterip öğretmiştir. İbn 'Acîbe'ye (öl. 1224/1809) göre Yüce Allah kargayla Kâbil'e kardeşinin cesedini ne yapacağını öğretmiştir, çünkü yeryüzünde daha önce ölen insan olmadığı için kâtil mütehayyir kalmıştır. ${ }^{65}$ Mazharî'nin (öl. 1225/1810) konuyla ilgili özel bir vurgusu olmamakla beraber ilgili hadîslere önemle yer vererek cumhura katıldığ görülmektedir. ${ }^{66}$ Şevkânî (öl. 1250/1835) ise iki görüşü art arda verdikten sonra, İbn 'Atıyye'nin cumhurun görüşüne muhalif nakle karşı verdiği cevabi zikreder. ${ }^{67}$

Âlûsî (öl. 1270/1854) ağırlıklı olarak ilgili rivâyetleri ve kadîm müfessirlerin görüşlerini aktardığı detaylı açıklamasında, bahis mevzuu iki kişi hakkındaki iki görüşü zikrettikten sonra "Yüce Allah'ın eli cemaatle beraberdir"68 diyerek cumhurun görüşünü desteklediğini izhar eder. Müellif farklı olarak, Ebû Bekir el-Asamm'a göre Hâbil'in cesedinin Yüce Allah'ın gönderdiği şey her ne ise onun tarafından gömüldüğü şeklindeki görüşü aktarır. Bu yorum muhtemelen, yine Müellifin "Bazıları şöyle demiştir" diye aktardığı, "O, karga suretinde

62 Muhammed b. Muhammed b. Mustafa Ebu's-Su'ûd el-'İmâdî, İrşâdu'l- 'akli's-selîm ilâ mezâye'l-Kitabi'l-Kerîm (Beyrut: Dâru İhyai't-Türâsi'l-Arabî, ts.), 3/26.

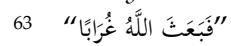

64 İsmail Hakkı Bursevî, Rûhu'l-Beyân (Beyrut: Dâru'l-Fikr, ts.), 2/379, 384.

65 Ebu'l-Abbas Ahmed b. Muhammed el-Hasanî İbn 'Acîbe, el-Bahru'l-medîd fî tefsîri'lKur'âni'l-Mecîd, thk. Ahmed Abdullah el-Kureşî Ruslan (Kâhire: y.y., 1999), 2/31.

66 Muhammed Senâullah Pânîpetî el-Mazharî, Tefsîru'l-Mazharî, thk. Ğulam Nebî etTûnisî (Pakistan: Mektebetü'r-Rüşdiyye, 1992), 3/78-83.

${ }^{67}$ Muhammed b. Ali b. Muhammed el-Yemenî eş-Şevkânî, Fethu'l-Kadîr (Beyrut: Dâru'l-Kelimi't-Tayyib, 1992), 2/36.

"ويد الله تعالى مع الجماعة" 68 
128 | Y. Emre GÖRDÜK / Klasik ve Modern Kaynaklarda Illk Cinayet Kıssası (Maide 5/27-31):

Tefsir Metodolojisi Açısından Mukayeseli Bir İnceleme

ortaya çıkan bir melekti." görüşüne dayanmaktadır. Âlûsî’ye göre Hasan el-Basrî, Ebû Müslim ve Cübbâî'nin görüşü uygun değildir, çünkü âyette defin hadisesinin öğretilmesinden bahsedilmektedir. ${ }^{69}$

Yukarıda Hâkim el-Cüşemî'nin tefsirinden alıntıladığımız kısımda Ebû Müslim el-Isfahânî ve Ebû Ali'nin cumhurla aynı görüşte olduğu belirtilmişti. Burada ise Âlûsî'nin tam aksini söylediği görülmektedir. Görünen o ki Âlûsî'nin aktarımında bir zuhûl söz konusudur. Nitekim Ebû Müslim'in, Hz. Âdem ve eşinin ilk iki insan olduğu konusunda diğer bütün ulemâ ile hemfikir olduğu görülmektedir. ${ }^{70}$

Makale boyutunu aşmamak adına eserlerde değinilen her konuya değil daha ziyade ilgilendiğimiz noktalarla ilgili izâhlara yer verileceğini başta belirtmiştik. Genel anlamda bakılacak olursa, Mâturîdî'den Âlûsî̀ye uzanan çizgide müfessirlerin tamamı $\mathrm{Hz}$. Âdem'in ilk insan olduğu, eşi ile beraber ikisinin ilk insan çifti olduğu konusunda ittifak halindedir. Kıssada geçen iki kişinin Hz. Âdem'in oğulları olduğu da neredeyse hepsi tarafından tercih edilen görüştür. Bazı müfessirlerin açıkça tercih belirtmediği görülmekte ancak genel ifadelerinden yaklaşımlarının ne olduğu anlaşılmaktadır. Yine ekserisi, eserlerinde ilgili rivâyetlere ve özellikle sahîh hadîslere yer verip bunları sahip oldukları kanaate delil addetmiştir. Müfessirlerin çoğunun karganın yaptığı kılavuzluğu delil olarak kullandığı da görülmektedir. Metodolojik açıdan dirâyet ağırlıklı tefsirlerde de ana ekseni konuyla ilgili sahih rivâyetlerin belirlediği görülmektedir. İlk muhataplar olan ashâbın anlayışı; onların ardından gelen tâbiî bilginlerin görüş ve yorumları birbirini teyit eder mâhiyette ve ittifak halindedir. Bunun yanı sıra âyetlerin zâhiri nazara alınmış ve te'vîl yoluna gidilmemiştir, çünkü te'vîli gerektirecek bir durum söz konusu değildir. Ayrıca hem âyet içi hem de âyetler ve sûreler arası bağlam unsurları göz önüne alınmıştır. Bunlara ek olarak iki kardeşin İsrâiloğulları'ndan olması halinde katil

69 Şihâbuddin Mahmud b. Abdillah el-Hüseynî el-Âlûsî, Rûhu'l-me 'ânî fì tefsîri'lKur'âni'l-Azîm ve's-Seb'i'l-Mesânî, thk. Ali Abdülbârî 'Atıyye (Beyrut: Dâru'l-Kütübi'lIlmiyye, 1993), 3/282-288.

70 Ebû Müslim el-Isfahânî, Tefsîru Ebî Müslim Muhammed b. Bahr el-Isfahânî, ed. Hıdr Muhammed Nebhâ (Beyrut: Dâru'l-Kütübi'l-İlmiyye, ts.), 36, 96, 121. 
Y. Emre GÖRDÜK / The Story of the First Murder (Surah al-Maidah/27-31) in Classic and Modern Sources: A Comparative Examination in Terms of Tafsir Methodology I 129 kardeşin bir ölünün nasıl defnedileceğini bileceği hususuna özel vurgu yapılmış ve ilkin Taberî̀nin dikkat çektiği bu aklî delile önem verilmiştir.

\section{Kissas1}

4. Çağdaş Tefsirlerde ve Diğer Bazı Çalışmalarda İlk Cinayet

Bu başlık altında daha ziyade yakın zamanda telif edilmiş bazı tefsirlere ve ele alınan âyetlere değinen çalışmalara kısaca değinilecektir. Çağdaş tefsirler denince hemen akla gelen müfessirlerden Elmalılı Hamdi (öl. 1942),,$^{71}$ Merâğ̂̀ (öl. 1952), ${ }^{72}$ Seyyid Kutub (öl. 1966), ${ }^{73}$ İbn 'Âşûr (öl. 1973), ${ }^{74}$ Mevdûdî (öl. 1979), ${ }^{75}$ Şa'râvî (öl. 1998), ${ }^{76}$ Vehbe Zuhaylî (öl. 2015), ${ }^{77}$ Cezâirî (öl. 2018) ${ }^{78}$ gibi isimlerin, yeryüzündeki ilk insan çiftinin Hz. Âdem ve eşi olduğu konusunda herhangi bir tereddüt içerisinde olmadıkları görülmektedir. Kıssada geçen iki kişi konusunda da durum aynıdır. İstisna belirtmek gerekirse Elmalılı Hamdi "kıssadan istifade için eşhasın tayin-i hüvviyetleri lazım değildir" görüşündedir. Seyyid Kutub da aynı düşüncededir. Bu bakış açısı daha önce Mâturîdî'de görülmüştü. Merâğî ise bazı konularda Abduh'un görüşlerinden etkilenmişse de ilk insan çiftinin Hz. Âdem ve Havvâ olduğunu kabul etmektedir. ${ }^{79}$ Cumhurun genel perspektifinin ne olduğu

71 Bk. Elmalılı Muhammed Hamdi Yazır, Hak Dîni Kur'ân Dili (İstanbul: Eser Neşriyat, 1979), 3/1651-1656.

72 Bk. Ahmed Mustafa el-Merâğî, Tefsîru'l-Merâğ $̂ \hat{~}$ (Misır: Matbaatu Mustafa el-Bâbi'lHalebî, 1946), 6/95-101.

73 Bk. Seyyid Kutub, Fî zılâli'l-Kur'ân (Kahire: Dâru'ş-Şurûk, 1991), 1/56-61, 215, 571-575; 2/872-877.

74 Bk. Muhammed et-Tâhir b. Muhammed İbn 'Âşûr, Tahrîru'l-ma 'na's-sedîd ve tenvîru'l'akli'l-cedîd min tefsîri'l-Kitâbi'l-Mecîd (Tûnus: Dâru't-Tûnusiyye, 1984), 6/169-173.

75 Bk. Ebu'l-A'lâ el-Mevdûdî, Tefhîmu'l-Kur'ân, çev. Muhammed Han Kayani vd. (İstanbul: İnsan Yayınları, 2005), 1/474-475.

76 Bk. Muhammed Mütevelli eş-Şa' râvî, Tefsîru'ş-Şa'râvî (el-Havâtır) (Mısır: Matâbi“u Ahbâri'l-Yevm, 1997), 5/3068-3085.

77 Bk. Vehbe b. Mustafa ez-Zuhaylî, et-Tefsîrü'l-münîr (Dımaşk: Dâru'l-Fikri'l-Mu'âsır, 1998), 6/151-159.

78 Bk. Câbir b. Mûsa b. Abdülkadir Ebû Bekir el-Cezâirî, Eyserü't-tefâsîr (Medîne: Mektebetü'1-Ulûm ve'1-Hikem, 2003), 1/619-621.

79 Merâğî, Tefsîr, 4/176-177; 26/141. 
130 | Y. Emre GÖRDÜK / Klasik ve Modern Kaynaklarda Illk Cinayet Kıssası (Maide 5/27-31):

Tefsir Metodolojisi Açısından Mukayeseli Bir İnceleme

üzerinde yeterince durulduğu için daha ziyâde modern çizgide seyreden bazı çalışmalardan birkaç örnek verilip sonuca geçilecektir.

Reşid Rıza (öl. 1935) cumhurun görüşü ile Hasan el-Basrî́den intikal eden görüşü aktardıktan sonra klasik tefsirlerde doğruluğu tayin edilemeyecek pek çok rivâyetin geçtiğini söyleyerek eleştirir. Bununla birlikte ikinci görüşün zayıf ve zâhirin hilafına olduğunu teslim eder. ${ }^{80}$ Ona göre de bu, yeryüzünde işlenen ilk cinayet olduğu için, katil kardeş cesedi ne yapacağını bilememiş; insanoğluna defin işi karga ile öğretilmiştir. ${ }^{81}$ Reşit Rıza'nın bu konuda üstadı Muhammed Abduh'tan (öl. 1905) farklı düşündüğü anlaşılmaktadır. Nitekim Allah ile melekler arasında Âdem hakkında geçen muhavereyi ve sonrasında anlatılanları müteşâbih addeden Abduh, ${ }^{82}$ Nisâ sûresinin ilk âyeti münasebetiyle insanların bir kısmının Âdem ve Havva'yı bilmedikleri gibi hiç duymamış olduklarını; dolayısıyla bu meşhur nesebin İbrânîlerden alındığını, oysa ilmî araştırmaların ve arkeolojik bulguların İbrânîlerin öngördüğü tarihin aksine olduğunu söyler. Örneğin daha eskiye uzanan bir tarihe sahip olan Çinliler, insanlığı başka bir babaya nisbet ederler. Müslümanlar da Yâhudilerin tarihini tasdik etmek zorunda değildir.

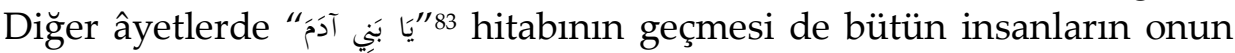
çocukları olduğunu gösteren kesin bir nas sayılmaz, çünkü tenzil zamanında bu hitabın Âdem'in evlatlarına tevcih edilmiş oluşu yeterlidir. Halbuki yeryüzünde ondan önce de böyle bir türün bulunduğu ve orada bozgunculuk çıkarıp kan döktükleri anlaşılmaktadır. Abduh'a göre İmâmiyye Şîası ve bazı Sûfilerden gelen çeşitli nakiller de bunu destekler. Söz konusu nakillere göre binlerce belki milyonlarca Âdem yaratılmıştır ve bildiğimiz insanoğlu en sonuncu Ấdemîlerdendir. ${ }^{84}$

Seyyid Ahmed Han'ın (öl. 1898) takipçilerinden ve Kur'âniyyûn ekolünden "Tulû-i İslam Hareketi"nin kurucusu olan Ġulâm Ahmed

80 Muhammed Reşid Rıza, Tefsîru'l-Kur'âni'l-Hakîm (Tefsîru'l-Menâr) (Misır: elHey'etü'1-Misriyyetü'1-‘Âmme li'1-Kitâb, 1990), 6/281-283.

81 Reşid Rıza, el-Menâr, 6/286.

82 Reşid Riza, el-Menâr, 1/210.

83 el-A'râf 7/26-27, 31, 35; Yâsîn 36/60.

84 Reşid Riza, el-Menâr, 4/265-267. 
Y. Emre GÖRDÜK / The Story of the First Murder (Surah al-Maidah/27-31) in Classic and Modern Sources: A Comparative Examination in Terms of Tafsir Methodology I 131 Perviz'e (öl. 1985) ${ }^{85}$ göre Âdem kıssası bütünüyle sembolik olup tüm insanları anlatmaktadır. Âdem özel bir şahsı değil insan ırkını temsil eder. Dolayısıyla Âdem ve eşinden bahseden âyetler özel bir insan çiftini ifade etmez. İlk cinayet kıssasında geçen iki kardeş sembolik olup burada Hz. İshak'in soyundan gelen Yahudilerin $\mathrm{Hz}$. İsmâil'in soyundan gelen Hz. Peygamber'e (s.a.s.) duyduğu kıskançlık mevzubahistir. Perviz bütün insanların kökeninin bir tek hücre olduğu düşüncesindedir. Süreç içinde evrimle var olan pek çok erkek ve kadının temeli olan bu hücreye "نَفْ وَاحِحَدة denilmiştir (en-Nisâ 4/1). Yeryüzünün daha önceki sakinlerini takiben yaşamda yerini alan Homo-sapiens belli bir aşamadan sonra Allah'ın emir ve yasaklarına muhatap olacak seviyeye gelmiştir. Perviz Kur'ân'ın sadece bir yerinde (Âl-i İmrân 3/33) "Âdem" isminin şahıs ifade ettiğini ve Nûh ile beraber anıldığını ancak âyetteki "صاصفَى " fiilinin peygamber olmayanlar için de kullanıldığını; dolayısıyla buradaki "Âdem"in kendi zamanında bu ismi taşıyan biri olabileceğini söyler. Onun peygamber olma ihtimali de vardır, fakat Kur'ân tarafından peygamberler arasında sayılmamış; peygamber anlatıları genel itibariyle Nûh ile başlatılmıştır (en-Nisâ 4/163). ${ }^{86}$

Muhammed Esed (öl. 1992) Nisâ sûresinin ilk âyetinde Abduh'a yaptığı atıfla Hz. Âdem ve eşi Havva'nın yaratılması konusunda Kitâb-1 Mukaddes tasvirlerini kabul etmenin yersiz olduğuna işaret eder. "Nefs"i bu bağlamda "canlı" olarak çevirmesinin gerekçesi de budur. Esed'e göre âyette geçen "minhâ" lafzına nazaran her iki cinsin bir tek canlıdan türetildiğine dâir biyolojik bir gerçek ifade edilmiştir. ${ }^{87}$ Abduh gibi Esed'e göre de Âdem-Havvâ kıssası; İblis, yasak ağaç, cennet ve

85 Bk. Abdülhamit Birışık, Hind Altkıtası Düşünce ve Tefsir Ekolleri (İstanbul: İnsan Yayınları, 2012), 421-444; Abdülhamit Birışık, "Pervîz, Gulam Ahmed", Türkiye Diyanet Vakfi İslam Ansiklopedisi (İstanbul: Türkiye Diyanet Vakfı, 2007), 34/247-249.

86 Gulâm Ahmed Perviz, Mefhûmu'l-Kur'ân (Lahor: Tulû-i İslâm, 2002), 248-249; Gulâm Ahmed Perviz, Metâlibu'l-Furkân (Lahor: Tulû-i İslâm, 1996), 2/4-15; Gulâm Ahmed Perviz, Metâlibu'l-Kur'ân fî dürûsi'l-Furkân-(Sûretü'n-Nisâ) (Lahor: Tulû-i İslâm, 2007), 47-68; Gulâm Ahmed Perviz, İblîs-u Âdem (Lahor: Tulû-i İslâm, 2000), 38-45; Ghulam Ahmad Parvez, Lughatu'l-Quran, çev. Sheraz Akhtar (Oslo: Quranic Education Society, 2015), 1/36-37.

87 Muhammed Esed, Kur'ân Mesajı, çev. Cahit Koytak - Ahmet Ertürk (İstanbul: İşâret Yayınları, 1999), 1/132-133. 
132 | Y. Emre GÖRDÜK / Klasik ve Modern Kaynaklarda Illk Cinayet Kıssası (Maide 5/27-31):

Tefsir Metodolojisi Açısından Mukayeseli Bir İnceleme

cennetten çıkarılma gibi unsurların hepsi sembolik olup insanoğlunun kozmik kaderinin temsilî bir anlatımıdır. ${ }^{88}$ Mâide 27-31. âyetlerdeki kıssa ise Tevrat'ın Tekvin bölümündeki Kâyin-Hâbil kıssasına atıftır ve Ehl-i Kitab'a hitaptır. Dolayısıyla Esed buradaki Âdem lafzını Hz. Âdem olarak almıştır. ${ }^{89}$ Öyle görünüyor ki Esed'e göre kıssanın nefsülemirde bir gerçekliği olmayıp Âdem-Havvâ kıssasının devamı niteliğinde sembolik bir anlatımdan ibarettir. Tevrat'a atıf yaptığı için de tıpkı Tevrat'ta anlatıldığ Hz. Âdem'in iki oğludur.

Süleyman Ateş evrim teorisinin Kur'ân âyetlerince desteklendiği görüşündedir ${ }^{90}$ hatta bu görüşü Elmalılı Hamdi Yazır gibi müfessirlerden yaptığ1 alıntılarla desteklemeye de çalışmıştır. ${ }^{91}$ Makalemize konu olan kıssayı ise kadîm müfessirlerin yolunu takip ederek yorumladığı görülmektedir. Buna göre, Yahudilere, Tevrat'ta okuyup öğrendikleri bir olay hatırlatılmakta, bilvesile kıskançlığın kötü sonucu ihtar edilmektedir. Yahudilerle Araplar Hz. İbrâhim (a.s.) kökeninde kardeştir. Kureyş'le kökende kardeş olan İsrâiloğulları ise Kureyş'in içinden çıkan peygamberi kıskanmıştır. Hasan ve Dahhâk'ın görüşü makul görünse de bahsedilen iki kişinin Hz. Âdem'in oğulları olması daha uygundur. İlkel yasalarda zorunlu olsa bile olgun şeriatlere aykırı düşen kardeşiyle evlenme olayından Kur'ân'da bahsedilmemiştir. İnsanlık tarihinin çok ilerlemiş döneminde gelen bir kavmin ölü gömmeyi bilmemesi ise makul değildir. $\mathrm{Bu}$ bakımdan kıssada anlatılanların Hz. Âdem'in oğulları olması siyâka ve akla daha uygundur. ${ }^{92}$

Kur'ân'da genel anlamda kıssaları, özelde Hz. Âdem'le ilgili anlatımları sembolik görenler açısından kıssada bahsi geçen iki kişi hakkında yapılacak bir tespitin gereği ve önemi yoktur. Zira Hz. Âdem,

88 Esed, Kur'ân Mesajl, 1/13, 273-274.

89 Esed, Kur'ân Mesajı, 1/192.

90 Süleyman Ateş, "Kur'ân-1 Kerîm'e Göre Evrim Teorisi", Ankara Üniversitesi İlahiyat Fakültesi Dergisi 20 (1975), 127-146.

91 Bk. Yunus Emre Gördük, “Elmalılı Hamdi Hz. Âdem'in Evrimle Yaratıldığını mı Söylüyor? (Süleyman Ateş'in İddiası Üzerine Bir İnceleme)", Süleyman Demirel Üniversitesi İlahiyat Fakültesi Dergisi 42 (Haziran 2019), 27-42.

92 Ateş, Yüce Kur'ân'ın Çağdaş Tefsiri (İstanbul: Yeni Ufuklar Neşriyat, 1997), 2/508-512. 
Y. Emre GÖRDÜK / The Story of the First Murder (Surah al-Maidah/27-31) in Classic and Modern Sources: A Comparative Examination in Terms of Tafsir Methodology I 133 eşi ve çocukları hakkındaki bahislerin vakıa itibariyle reel bir karşılığ bulunmamaktadır. Bununla beraber kıssada Tekvin'e atıf yapıldığı da düşünülürse izlenecek yol, herhangi bir açıklama yapmaya gerek duymaksızın âyetin zâhirinde ne deniyorsa onun aktarılmasından ibarettir. ${ }^{93}$ Kezâ hem kıssanın sembolik olduğu hem de insanın süreç içinde evrimle yaratıldığı görüşünde olanlar için de herhangi bir tespit yapmaya gerek yoktur. ${ }^{94}$ Zira evrime göre ilk insan çifti diye bir şey söz konusu olmadığ Burada bir parantez açmak gerekirse; modern dönem araştırmacılarının evrim düşüncesine, Hz. Âdem'in (a.s.) çocuklarının kendi aralarında evlenmesi durumunun ensest ilişki olacağı mülahazasıyla vardığını söylememiz gerekmektedir. Oysaki yeryüzünde henüz başka ailelerin olmadı $\breve{g} 1$; mahrem ve namahrem, aile ve aile dışı kavramlarının zihinsel şemaya henüz dâhil olmadığı bir zamanda, günümüzdeki karşılığıyla ensestten bahsedilemeyeceği gibi evrimle tekâmül eden ve nikâh akdinin ne olduğunu bile bilmeyen ilkel/insan altı canlıların soyundan gelmenin daha makul ve insan şerefine daha uygun olduğu da iddia edilemez. ${ }^{55}$ Tekrar konumuza dönecek olursak; gördüğümüz kadarıyla ilk cinayet kıssasının sembolik olduğunu ve Tevrat'a atfen zikredildiğini söyleyenlerin, Tekvin'deki anlatıda bulunmayan karga unsurunun Kur'ân'da niçin zikredildiğine dair kayda değer bir açıklaması

93 Bk. Muhammed Ahmed Halefullah, el-Fennü'l-kasâsî fi'l-Kur'âni'l-Kerîm (Beyrut: Müessesetü'l-İntişâri'l-Arabî/Sîna, 1999), 182-184; Muhammed Ferid Vecdi, elMushafu'l-Müfesser (Kahire: Daru'ş-Şa'b, 1977), 8; Mustafa Öztürk, Kıssaların Dili (Ankara: Ankara Okulu Yayınları, 2010), 101-172; Mustafa Öztürk, Kur'an-ı Kerim Meali-Anlam ve Yorum Merkezli Çeviri (Ankara: Ankara Okulu Yayınları, 2014), 37-38, 145-146, 187-188; R. İhsan Eliaçı, Yaşayan Kur'an-Türkçe Meal-Tefsir (İstanbul: İnşa Yayınları, 2014), 1031.

94 Bk. Mustafa İslamoğlu, Nüzul Sırasına Göre Hayat Kitabı Kur'an (İstanbul: Düşün Yayıncılık, 2010), 705-708, 923; Mustafa İslamoğlu, Yaratılış ve Evrim (İstanbul: Düşün Yayıncilık, 2018), 189-205, 224-236, 241-246; Mehmet Okuyan, Kıssalar Ne Söyler (İstanbul: Düşün Yayıncllık, 2017), 61-86; Eliaçık, Yaşayan Kur'an, 450, 456, 517, 623629, 661, 760-761, 1031-1034; Caner Taslaman, Bir Müslüman Evrimci Olabilir mi? (İstanbul: Destek Yayınları, 2017), 59-115.

95 Konuyla ilgili müstakil ve detaylı bir analiz için bk. Yunus Emre Gördük, "İlk İnsan Nesli Nasıl Devam Etti? Ensest İlişki İddiası Üzerine Eleştirel Bir Analiz", Usul İslam Araştırmaları 29 (2018), 69-97. 
134 | Y. Emre GÖRDÜK / Klasik ve Modern Kaynaklarda Illk Cinayet Kıssası (Maide 5/27-31):

Tefsir Metodolojisi Açısından Mukayeseli Bir İnceleme

bulunmamaktadır. ${ }^{96}$ Öte yandan sembolik olduğu düşünülen anlatımların istenen her şekilde yorumlanması da mümkündür. Hem kıssanın sembolik olduğu düşüncesine hem de insanoğlunun günümüze ilk insan çiftinin nesli olarak değil evrimle geldiği düşüncesine göre 27.

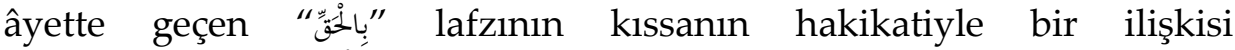
bulunmamaktadır. Âyete verilen meâller, sahip olunan bu anlayışa göre "gerçek bir amaca matuf olarak anlat",, 7 "ibret vesilesi olarak anlat",, 8 “...kıssasının gerçeğini anlat" ${ }^{\prime 99}$ gibi ifadelerle yapılmıştır.

\section{Sonuç}

Çalışmamız açısından kıssanın en önemli iki noktası, "Âdem'in iki oğlu" ile kimlerin kastedildiği ve bir karganın yaptığı rehberliğin ne ifade ettiğidir. Kanaatimizce 27. âyetle başlayan kıssada, sûrenin ilk 26 âyetinde ilgi çekilen haset odağ 1 taifelerin tümünü kapsar mahiyette ilk insanın ilk çocuklarından örnek verilmesi gayet hikmetlidir. Bu açıdan hitap sadece Yahudilere değildir. Taberî̀nin son derece orijinal bakış açısıyla, kurban sunmanın Âdemoğulları'na mahsus bir ibadet olduğu herkesin malumu iken "Âdem'in iki oğlu" ifadesi herhangi iki insanı değil Hz. Âdem'in iki oğlunu vurguluyor olmalıdır. Eserleri gözden geçirilen müfessirlerin tamamına yakını Âdemoğulları içinde cinayet yolunu ilk açan şahıstan bahseden hadîsleri göz önüne almıştır. Özellikle Mesrûk'un Abdullah b. Mes'ûd'dan naklettiği ve neredeyse bütün sahîh kaynaklarda yer alan hadîsin cerhedilmesi mümkün görünmemektedir. Bazı hadîs rivâyetlerinde doğrudan Mâide sûresi 2731. âyetlerle ilgi kurulduğu da görülmektedir. Buna sahâbe ve tâbiûn görüşleri ile ümmetin ittifakı da eklenince kâtil ve maktûlün kimler olduğu konusu netlik kazanmıştır. Ayrıca cesedin nasıl örtüleceğini göstermesi için gönderilen karga da bu kanaati teyit etmektedir. Nitekim ilk cinayeti işleyen ilk katil cesedi ne yapacağını bilememiştir. Yapılan izahlarda gerek Mâide sûresinin gerekse farklı sûrelerin konuyla ilgili diğer âyetlerinin de göz önüne alındığı görülmektedir. Bunların yanı sıra, âyetlerin zâhiri esas tutulmuş ve herhangi bir tereddüt yahut işkâl

96 Bk. Öztürk, Kıssaların Dili, 157-172; Okuyan, Kıssalar Ne Söyler, 195-207.

97 İslamoğlu, Hayat Kitabı Kur'an, 923.

98 Öztürk, Kur'an-ı Kerim Meali, 145.

99 Eliaçık, Yaşayan Kur'an, 1031. 
Y. Emre GÖRDÜK / The Story of the First Murder (Surah al-Maidah/27-31) in Classic and Modern Sources: A Comparative Examination in Terms of Tafsir Methodology I 135 durumu söz konusu olmadığ 1 için te'vile ihtiyaç duyulmamıştır. Bütün bunlar aynı zamanda klasik tefsirlerde izlenen metodun temel unsurlarını oluşturmaktadır.

Yirminci asra gelininceye kadar bir iki istisna haricinde müfessirlerin tamamının ittifak halinde olduğu görülmektedir. Aykırı görüş belirttiği nakledilen Hasan el-Basrî ve Dahhâk gibi zâtlar kelâmin siyâkı itibariyle kendi anladıklarını ortaya koymuş olmalıdır. Nitekim bu görüşün Hz. Âdem ve eşinin ilk insan çifti olmadığı şeklindeki bir düşünceyle ilgisinin olmadığı yine bu zâtlardan gelen başka rivâyetlerle sâbittir. Ele aldığımız konuyu tartışmaya lüzum görmeyen müfessirlerin de kıssayı Hz. Âdem ve Kâbil-Hâbil isimleri üzerinden tefsir ettiği görülmektedir. $\mathrm{Bu}$ açıdan herkesçe müsellem ve makbul bir Âdem anlayışı söz konusudur. Dolayısıyla bu şaz yorumun ilk yapıldığı zamanki sâiki ile bugün desteklenmesinin altında yatan sâik şüphesiz ki aynı değildir. Günümüzde evrim düşüncesi perspektifine uygun görülen bu haber, böyle bir tartışmanın henüz olmadığı bir zaman diliminde aktarılmış ve müfessirlerce tenkit edilmiştir. Kur'ân kıssalarının sembolik olduğuna dair, özellikle 19. asrın sonlarında dikkat çekip 20. asırda intişar eden ve son zamanlarda gündemde tutulan anlayış da evrim düşüncesiyle birlikte modernist yaklaşımın dayandığ ikinci unsurdur.

Sonuç itibariyle iki kardeşten biri diğerini katletmiş; daha sonra maktulün ortada kalan cesedini ne yapacağını bilememiş ve nihâyet onun defnedilmesi gerektiğini bir kargadan öğrenmiştir. Âyetin sarih ifadesi bu iki kişi için "Âdem'in iki oğlu" demektedir ve geçerli bir karine/delil olmadığ 1 müddetçe bu konuda yapılacak te'vîl ikna edicilikten uzaktır. Öte yandan Tevrat'ta da benzer bir anlatımın yer alması, bunun bir hakikat olarak Kur'ân'da tekrar anlatılmasına münâfî değildir. Kaldı ki söz konusu âyetlerle eğer sadece Tevrat'taki kıssa hatırlatılıyor olsa, ekleme yapılmaksızın aynen aktarılması beklenirdi. Zira Tekvin'de (Yaratılış) geçen Kâyin-Hâbil kıssasında kargadan bahsedilmemektedir. Ayrıca "hakk" diye tavsif edilerek anlatılan hadisenin Tevrat'taki anlatıya benzemesi şaşılacak bir durum değildir, çünkü o da asıl itibariyle semâvîdir. Kur'ân-1 Kerîm ise Tevrat ve İncil metinleri/hükümleri üzerinde mübeddil ve musahhih olduğu gibi bazen de mütemmim ve musaddık olmuştur. 
136 | Y. Emre GÖRDÜK / Klasik ve Modern Kaynaklarda Illk Cinayet Kıssası (Maide 5/27-31):

Tefsir Metodolojisi Açısından Mukayeseli Bir İnceleme

Evrimci düşünce, gerek gördüğü yerlerde âyetlerin medlûllerini kendi ön kabulüne göre yeniden dizayn etmektedir. Bu kapsamda Hz. Âdem'le ilgili anlatımların sembolik olduğu iddiası da bu düşünceyle örtüşen bir yapı arz etmektedir. Kıssaların tümüyle sembolik olduğu iddiası ise ele aldığımız ilk cinayet kıssası açısından, aslında yaşanmışlığı olmayan fakat insanlar tarafından öyle kabul edildiği için Kur'ân'ın da öyle aktardığı bir olaya, yine Kur'ân'ın hakikatte olmayan bir karga unsurunu ayrıca ilave ettiğini söylemiş olmaktadır. Kanaatimizce, kendini "hakk" diye tarif eden Allah kelâmı asılsız ve hayali sözlerden münezzehtir. Ayrıca genelde Âdem kıssası, özelde bu kıssa eğer sembolikse, Hz. Peygamber (s.a.s.) ve sahâbe dâhil olmak üzere on dört asır boyunca bütün ümmetin bunu idrâk edemediği sonucu doğmaktadır ki bundan söz etmek bile abestir. Öte yandan yeri geldiğinde âyetlerin ilk muhataplarınca anlaşılan şeklinin esas olduğundan bahseden bazı araştırmacıların, konu Kur'ân kıssaları olunca aktarılan hadîsleri ve sahâbenin anlayışını yansıtan onlarca rivâyeti gözardı etmesi de dikkate şâyân ayrı bir çelişkidir. Bu arada Âdem kıssasında anlatılanların bütün insanlara bakan yönlerinin olması ise Hz. Âdem'in bir şahıs olmasına aykırı değildir; bilakis Kelâmullah'ın câmi'iyyeti bu tür bir yoruma imkân sunmaktadır. Bu çerçevede özellikle sahîh rivâyetlere ve ilk muhatap kitlenin anlayış ve yorumlarına karşı müstağni davranan her iki yaklaşımın da sağlam birer ilmî temele dayanmadığı ve tefsir metodolojisi açısından problem çözmekten ziyade farklı çelişkileri ve soru işaretlerini beraberinde getirdiği âşikârdır. Buna karşın cumhurun lafzî delillerle birlikte hem sahîh hadîsleri hem de sahâbe ve tâbiûndan aktarılan rivâyetleri ihmâl etmeksizin ortaya koyduğu bütünleyici izâh perspektifi, hicrî ilk asırdan günümüze değin süreğen, tutarlı ve sihhatli bir tefsir metodolojisi sunmuş olarak gözler önündedir.

\section{Kaynakça}

Abdürrezzak es-San'ânî. Tefsîru Abdirrezzak. thk. Mahmud Muhammed Abduh. 3 Cilt. Beyrut: Dâru'l-Kütübi'l-i̇lmiyye, 1998.

Ahmed b. Hanbel, Ebu Abdillah. Müsned. thk. Şuayb el-Arnaût vd.. 45 Cilt. Beyrut: Müessesetü'r-Risale, 2001. 
Y. Emre GÖRDÜK / The Story of the First Murder (Surah al-Maidah/27-31) in Classic and Modern Sources: A Comparative Examination in Terms of Tafsir Methodology I 137

Âlûsî, Şihâbuddin Mahmud b. Abdillah el-Hüseynî. Rûhu'l-me'ânî fì tefsîri'l-Kur'âni'l-Azîm ve's-Seb'i'l-Mesânî. thk. Ali Abdülbârî 'Atıyye. 16 Cilt. Beyrut: Dâru'l-Kütübi'l-i̇lmiyye, 1993.

'Askalânî, İbn Hacer. Fethü'l-Bârî alâ Sahîhi'l-Buhârî. 13 Cilt. Beyrut: Dâru'l-Ma'rife, 1959.

Ateş, Süleyman. "Kur'ân-1 Kerîm'e Göre Evrim Teorisi". Ankara Üniversitesi İlahiyat Fakültesi Dergisi 20 (1975), 127-146.

Ateş, Süleyman. Yüce Kur'ân'ın Çağdaş Tefsiri. 10 Cilt. İstanbul: Yeni Ufuklar Neşriyat, 1997.

Beğavî, Ebû Muhammed el-Hüseyin b. Mes'ûd b. Muhammed b. elFerrâ. Me'âlimu't-Tenzîl fi Tefsîri'l-Kur'ân. thk. Abdürrezzak elMehdî. Beyrut: Dâru İhyai't-Türâsi'l-Arabî, 1998.

Beydâvî, el-Kâdî Nâsıruddîn Ebî Sa'îd Abdullah b. Ömer. Envârü̈'t-tenzîl ve esrârü't-te'vîl. thk. Muhammed Abdurrahman el-Mar`aşlî. 5 Cilt. Beyrut: Daru İhyai't-Türasi'l-Arabî, 1997.

Bikâ'î, Ebu'l-Hasan Burhanüddin İbrahim b. Ömer. Nazmu'd-dürer fi tenâsübi'l-âyâti ve's-suver. 22 Cilt. Kâhire: Dâru'l-Kütübi'l-İslâmî, ts.

Birışık, Abdülhamit. Hind Altkıtası Düşünce ve Tefsir Ekolleri. İstanbul: İnsan Yayınları, 2. Basım, 2012.

Birışık, Abdülhamit. "Pervîz, Gulam Ahmed". Türkiye Diyanet Vakfı İslam Ansiklopedisi. 34/247-249. İstanbul: Türkiye Diyanet Vakfı, 2007.

Buhârî, Ebû Abdullah İsmail b. İbrahim el-Cu'fî. Sahîh. thk. Muhammed Hüseyin b. Nâsır en-Nâsır. 9 Cilt. Beyrut: Dâru Tavki'n-Necât, 2002.

Bursevî, İsmail Hakkı. Rûhu'l-Beyân. 10 Cilt. Beyrut: Dâru'l-Fikr, ts.

Cezâirî, Câbir b. Mûsa b. Abdülkadir Ebû Bekir. Eyserü't-tefâsîr. 5 Cilt. Medîne: Mektebetü'l-Ulûm ve'l-Hikem, 2003.

Ebû Hafs en-Nesefî, Necmüddîn Ömer b. Muhammed. et-Teysîr fi't-tefsîr. thk. Mâhir Edîb Habbûş. Beyrut: Dâru'l-Lübâb, 2019.

Ebû Hayyân, Esîrüddin Muhammed Yûsuf b. Ali. el-Bahru'l-muhît fi'ttefsîr. thk. Sidkî Muhammed Cemil. 10 Cilt. Beyrut: Dâru'l-Fikr, 1999.

Ebû Müslim el-Isfahânî. Tefsîru Ebî Müslim Muhammed b. Bahr el-Isfahânî. ed. Hidr Muhammed Nebhâ. Beyrut: Dâru'1-Kütübi'l-İlmiyye, ts. 
138 | Y. Emre GÖRDÜK / Klasik ve Modern Kaynaklarda Illk Cinayet Kıssası (Maide 5/27-31):

Tefsir Metodolojisi Açısından Mukayeseli Bir İnceleme

Ebu's-Su'ûd el-'İmâdî, Muhammed b. Muhammed b. Mustafa. İrşâdu'l'akli's-selîm ilâ mezâye'l-Kitabi'l-Kerîm. 9 Cilt. Beyrut: Dâru İhyai'tTürâsi'l-Arabî, ts.

Eliaçık, R. İhsan. Yaşayan Kur'an-Türkçe Meal-Tefsir. İstanbul: İnşa Yayınlar1, 2014.

Esed, Muhammed. Kur'ân Mesajı. çev. Cahit Koytak - Ahmet Ertürk. 3 Cilt. İstanbul: İşâret Yayınları, 1999.

Dahhâk b. Müzâhim. Tefsîru'd-Dahhâk. ed. Muhammed Şükri Ahmed ezZâviyetî. 2 Cilt. Kâhire: Dâru's-Selâm, 1999.

Gördük, Yunus Emre. “Elmalılı Hamdi Hz. Âdem'in Evrimle Yaratıldığını mı Söylüyor? (Süleyman Ateş'in İddiası Üzerine Bir İnceleme)". Süleyman Demirel Üniversitesi İlahiyat Fakültesi Dergisi 42 (Haziran 2019), 27-42.

Gördük, Yunus Emre. "İlk İnsan Nesli Nasıl Devam Etti? Ensest İlişki İddiası Üzerine Eleştirel Bir Analiz". Usul İslam Araştırmaları 29 (2018), 69-97.

Hâkim el-Cüşemî, Ebû Sa'd el-Muhassin b. Muhammed b. Kerrâme. etTehzîbu fi't-tefsîr. 10 Cilt. Kahire/Beyrut: Dâru'l-Kütübi'lMisriyye/Dâru'l-Kütübi'l-Lübnâniyye, 2018.

Halefullah, Muhammed Ahmed. el-Fennü̈l-kasâsî fi'l-Kur'âni'l-Kerîm. Beyrut: Müessesetü'l-İntişâri'l-Arabî/Sîna, 1999.

Hasan el-Basrî. Tefsîru'l-Hasani'l-Basrî. ed. Muhammed Abdürrahim. 2 Cilt. Kâhire: Dâru'l-Hadîs, ts.

Hâzin, Alâuddîn Ali b. Muhammed b. İbrâhim. Lübâbü't-te'vîl fî me'âni'ttenzîl. thk. Muhammed Ali Şahin. 4 Cilt. Beyrut: Dâru'l-Kütübi'lİlmiyye, 1994.

Humeydî, Ebû Bekir Abdullah b. ez-Zübeyr el-Kureşî. Müsnedu'lHumeydî. thk. Hasan Selim Esed ed-Dârânî. 2 Cilt. Dımaşk: Dâru'sSekâ, 1996.

İbn 'Acîbe, Ebu'l-Abbas Ahmed b. Muhammed el-Hasanî. el-Bahru'lmedîd fì tefsîri'l-Kur'âni'l-Mecîd. thk. Ahmed Abdullah el-Kureşî Ruslan. 7 Cilt. Kâhire: y.y., 1999.

İbn 'Âdil, Ebû Hafs Siracüddîn Ömer b. Ali. el-Lübâb fî 'ulûmi'l-Kitab. thk. Adil Ahmed Abdülmevcud - Ali Muhammed Mu'avvıd. 20 Cilt. Beyrut: Dâru'l-Kütübi'l-İlmiyye, 1998. 
Y. Emre GÖRDÜK / The Story of the First Murder (Surah al-Maidah/27-31) in Classic and Modern Sources: A Comparative Examination in Terms of Tafsir Methodology I 139

İbn 'Âşûr, Muhammed et-Tâhir b. Muhammed. Tahrîru'l-ma'na's-sedîd ve tenvîru'l-'akli'l-cedîd min tefsîri'l-Kitâbi'l-Mecîd. 30 Cilt. Tûnus: Dâru't-Tûnusiyye, 1984.

İbn 'Atıyye, Ebû Muhammed Abdülhak b. Galib. el-Muharreru'l-vecîz fì tefsîri'l-Kitâbi'l-'Azîz. thk. Abdüsselam Abdüşşafî Muhammed. Beyrut: Dâru'l-Kütübi'l-İlmiyye, 2000.

İbnü'l-Cevzî, Ebu'l-Ferec Cemâlüddin Abdurrahman. Zâdu'l-mesîr fì ilmi't-tefsîr. thk. Abrürrezzak el-Mehdî. 4 Cilt. Beyrut: Dâru'lKitâbi'l-Arabî, 2001.

İbn Cüzey, Ebu'l-Kâsım Muhammed b. Ahmed. et-Teshîl li 'ulûmi't-tenzîl. thk. Abdullah el-Hâlidî. 2 Cilt. Beyrut: Şeriketu Dâri'l-Erkam b. Ebî'l-Erkam, 1995.

İbn Ebî Hâtim, Ebû Muhammed Abdurrahman b. Muhammed. Tefsîru'lKur'âni'l-'Azîm. thk. Es'ad Muhammed Tayyib. 10 Cilt. Suudi Arabistan: Mektebetü Nizâr, 1998.

İbn Ebî Şeybe, Ebû Bekir Abdullah b. Muhammed b. İbrahim b. Osman. Müsned. thk. Yûsuf el-Azâzî - Ahmed b. Ferîd el-Mezîdî. 2 Cilt. Riyad: Dâru'l-Vatan, 1992.

İbn Kesîr, Ebû'l-Fidâ İsmail b. Ömer el-Kureşî. Tefsîru'l-Kur'âni'l-Azîm. thk. Sami b. Muhammed Selâme. 8 Cilt. Misır: Dâru't-Taybe, 1999.

İbn Mâce, Ebû Abdullah Muhammed b. Yezid er-Rebeî el-Kazvinî. Sünen. thk. Muhammed Fuâd Abdülbaki. 2 Cilt. Beyrut: Dâru İhyai'l-Kütübi'l-Arabiyye, ts.

İbn Sa'd, Ebû Abdillah Muhammed. et-Tabakâtü'l-Kübrâ. thk. Muhammed Abdülkadir 'Atâ. 8 Cilt. Beyrut: Dâru'l-Kütübi'lİlmiyye, 1990.

İslamoğlu, Mustafa. Nüzul Sırasına Göre Hayat Kitabı Kur'an. İstanbul: Düşün Yayıncılık, 2010.

İslamoğlu, Mustafa. Yaratılış ve Evrim. İstanbul: Düşün Yayıncılık, 2018.

Kâsımî, Muhammed Cemâlüddin b. Muhammed Sa'îd. Mehâsinü't-te'vîl. 9 Cilt. Beyrut: Dâru'1-Kütübi'l-İlmiyye, 1996.

Kurtubî, Şemsüddîn Ebû Abdillah Muhammed b. Ahmed el-Hazrecî. elCâmi' li-ahkâmi'l-Kur'ân. thk. Ahmed el-Berdûnî - İbrâhim Atfîş. 20

Cilt. Kahire: Dâru'l-Kütübi'l-Misriyye, 1964.

Kutsal Kitap (Tevrat, Zebur, Incil). İstanbul: Kitab-1 Mukaddes Şirketi Yeni Yaşam Yayınları, 2010. 
140 | Y. Emre GÖRDÜK / Klasik ve Modern Kaynaklarda Illk Cinayet Kıssası (Maide 5/27-31):

Tefsir Metodolojisi Açısından Mukayeseli Bir İnceleme

Mâtürîdî, Ebû Mansûr Muhammed. Te'vîlâtü'l-Kur'ân. thk. Mecdî Bâslûm. 10 Cilt. Beyrut: Daru'l-Kütübi'l-İlmiyye, ts.

Mâverdî, Ebu'l-Hasan Ali b. Muhammed. en-Nüket ve'l-'uyûn. thk.

Seyyid b. Abdilmaksûd b. Abdirrahim. 6 Cilt. Beyrut: Dâru'l-

Kütübi'l-ìlmiyye, ts.

Mazharî, Muhammed Senâullah Pânîpetî. Tefsîru'l-Mazharî. thk. Ğulam

Nebî et-Tûnisî. 10 Cilt. Pakistan: Mektebetü'r-Rüşdiyye, 1992.

Mekkî b. Ebî Talib, Ebû Muhammed. el-Hidâye ilâ bulûği'n-nihâye fî İlmi me'âni'l-Kur'ân ve Tefsîrihi. thk. Heyet. 13 Cilt. Birleşik Arap Emirlikleri: Câmiatu'ş-Şârika/Külliyetü'ş-Şeria ve'd-Dırâsâti'lİslâmiyye, 2008.

Merâğî, Ahmed Mustafa. Tefsîru'l-Merâğ̂̀i. 30 Cilt. Misır: Matbaatu Mustafa el-Bâbi'l-Halebî, 1946.

Mevdûdî, Ebu'l-A'lâ. Tefhîmu'l-Kur'ân. çev. Muhammed Han Kayani vd.. 7 Cilt. İstanbul: İnsan Yayınları, 2005.

Mukâtil b. Süleyman. Tefsîru Mukâtil b. Süleyman. thk. Abdullah Mahmud Şehâte. 5 Cilt. Beyrut: Dâru İhyai't-Türâs, 2001.

Mücâhid b. Cebr. Tefsîru Mücâhid. thk. Mahmud Abdüsselam Ebû'n-Nîl. Misır: Dâru'l-Fikri'l-İslâmiyyi'l-Hadîse, 1989.

Müslim, Ebü'l-Hüseyn Müslim b. el-Haccâc. Sahihu Müslim. 5 Cilt. Beyrut: Daru İhyai't-Turasi'l-Arabi.

Nesâ̂,, el-İmam Ebû Abdirrahman Ahmed b. Şuayb. Sünen. thk. Abdülğaffar Süleyman el-Bendârî - Seyyid Küsrevî Hasan. 6 Cilt. Beyrut: Dâru'l-Kütübi'l-İlmiyye, 1991.

Nesefî, Ebu'l-Berekât Abdullah b. Ahmed b. Mahmûd Hâfızuddîn. Medârikü't-Tenzîl ve hakâiku't-te'vîl. thk. Yusuf Ali Bedîvî. 3 Cilt. Beyrut: Dâru'l-Kelimi't-Tayyib, 1998.

Neysâbûrî, Nizâmüddin el-Hasan b. Muhammed el-Kummî. Garâibu'lKur'ân ve reğâibu'l-Furkân. thk. Zekeriyya 'Umeyrat. 6 Cilt. Beyrut: Dâru'l-Kütübi'l-İlmiyye, 1995.

Nu'aym b. Hammâd el-Mervezî, Ebû Abdillah. Kitâbu'l-fiten. thk. Semîr Emin ez-Züheyrî. 2 Cilt. Kâhire: Mektebetü't-Tevhîd, 1991.

Okuyan, Mehmet. Kıssalar Ne Söyler. İstanbul: Düşün Yayıncılık, 2017. Öztürk, Mustafa. Kıssaların Dili. Ankara: Ankara Okulu Yayınları, 2010. Öztürk, Mustafa. Kur'an-ı Kerim Meali-Anlam ve Yorum Merkezli Çeviri. Ankara: Ankara Okulu Yayınları, 2014. 
Y. Emre GÖRDÜK / The Story of the First Murder (Surah al-Maidah/27-31) in Classic and Modern Sources: A Comparative Examination in Terms of Tafsir Methodology I 141

Parvez, Ghulam Ahmad. Lughatu'l-Quran. çev. Sheraz Akhtar. 4 Cilt. Oslo: Quranic Education Society, 2015.

Perviz, Gulâm Ahmed. İblîs-u Âdem. Lahor: Tulû-i İslâm, 6. Basım, 2000.

Perviz, Gulâm Ahmed. Mefhûmu'l-Kur'ân. Lahor: Tulû-i İslâm, 2. Basım, 2002.

Perviz, Gulâm Ahmed. Metâlibu'l-Furkân. Lahor: Tulû-i İslâm, 1996.

Perviz, Gulâm Ahmed. Metâlibu'l-Kur'ân fì dürûsi'l-Furkân-(Sûretü'nNisâ). Lahor: Tulû-i İslâm, 2007.

Râgıb el-Isfahânî. Tefsîrü'r-Râgıb el-Isfahânî. thk. Hind bint Muhammed b. Zâhid Serdâr. 2 Cilt. Mekke: Camiatu Ümmi'lKurâ/Külliyyetü'd-Da'veti ve Usûli'd-Dîn, 2001.

Râzî, Fahrüddîn Ebû Abdillah Muhammed b. Ömer. Mefâtîhu'l-gayb. 32 Cilt. Beyrut: Dâru İhyai't-Türâsi'l-Arabî, 1998.

Reşid Rıza, Muhammed. Tefsîru'l-Kur'âni'l-Hakîm (Tefsîru'l-Menâr). 12 Cilt. Misır: el-Hey'etü'l-Misriyyetü'l-'Âmme li'l-Kitâb, 1990.

Sa'lebî, Ebû İshak Ahmed b. Muhammed b. İbrahim. el-Keşf ve'l-Beyan an Tefsîri'l-Kur'ân. thk. Ebû Muhammed b. Âşûr. 10 Cilt. Beyrut: Dâru İhyai't-Türâsi'l-Arabî, 2002.

Se'âlibî, Ebû Zeyd Abdurrahman b. Muhammed. el-Cevâhiru'l-hisân fî̀ tefsîri'l-Kur'ân. thk. Muhammed Ali Mu'avvıd - Âdil Ahmed Abdülmevcûd. 5 Cilt. Beyrut: Dâru İhyai't-Türâsi'l-Arabî, 1997.

Sem'ânî, Ebu'l-Muzaffer Mansur b. Muhammed. Tefsîru'l-Kur'ân. thk.

Yâsir b. İbrâhim - Ğanîm b. Abbâs b. Ğanîm. 6 Cilt. Riyad: Dâru'lVatan, 1997.

Semerkandî, Ebu'l-Leys. Bahru'l-'Ulûm. 3 Cilt. b.y.: y.y., ts.

Seyyid Kutub. Fî zulâli'l-Kur'ân. 6 Cilt. Kahire: Dâru'ş-Şurûk, 1991.

Suyûtî, Celâlüddin Abdurrahman. ed-Dürrü'l-mensûr. 8 Cilt. Beyrut: Dâru'l-Fikr, ts.

Şa'râvî, Muhammed Mütevelli. Tefsîru'ş-Şa'râvî (el-Havâtır). 20 Cilt. Misır: Matâbi'u Ahbâri'l-Yevm, 1997.

Şevkânî, Muhammed b. Ali b. Muhammed el-Yemenî. Fethu'l-Kadîr. 6 Cilt. Beyrut: Dâru'l-Kelimi't-Tayyib, 1992.

Taberî, Ebû Ca'fer Muhammed b. Cerîr. Câmi'u'l-beyân fî te'vîli'l-Kur'ân. thk. Ahmed Muhammed Şakir. 24 Cilt. Beyrut: Müesseset'r-Risâle, 2000. 
142 | Y. Emre GÖRDÜK / Klasik ve Modern Kaynaklarda İlk Cinayet Kıssası (Maide 5/27-31):

Tefsir Metodolojisi Açısından Mukayeseli Bir İnceleme

Taberî, Ebû Ca'fer Muhammed b. Cerîr. Târîhu'r-rusul ve'l-mülûk. 11 Cilt. Beyrut: Dâru't-türâs, 1967.

Taslaman, Caner. Bir Müslüman Evrimci Olabilir mi? İstanbul: Destek Yayınları, 2017.

Tirmizî, Ebû İsa Muhammed b. İsa es-Sevre. el-Câmiu's-Sahîh (Sünenü Tirmizî). 5 Cilt. Mısır: Şeriketü'l Mektebe ve Matbaati Mustafa elBâbî'l-Halebî, 1975.

Vecdi, Muhammed Ferid. el-Mushafu'l-Müfesser. Kahire: Daru'ş-Şa'b, 1977.

Yazır, Elmalılı Muhammed Hamdi. Hak Dîni Kur'ân Dili. 10 Cilt. İstanbul: Eser Neşriyat, 1979.

Zuhaylî, Vehbe b. Mustafa. et-Tefsîrü'l-münîr. 30 Cilt. Dımaşk: Dâru'lFikri'l-Mu'âsır, 1998. 